\title{
WHY IS THE PAYOFF TO SCHOOLING SMALLER FOR IMMIGRANTS? *
}

\author{
Barry R. Chiswick \\ Department of Economics \\ University of Illinois at Chicago \\ and \\ IZA-Institute for the Study of Labor \\ and \\ Paul W. Miller \\ Business School \\ University of Western Australia
}

Keyword: Immigrants, Schooling, Occupations, Earnings, Rates of Return, Selectivity

JEL Codes: I21, J24, J31, J61, F22

* We thank Derby Voon for research assistance. We appreciate the very helpful comments received on earlier drafts of this paper from co-editor Katharine G. Abraham, two anonymous referees, and from participants at seminars at the University of Melbourne, Deakin University, the IZA Third Annual Migration Meeting, and the 2007 meeting of the Southern Economics Association. Chiswick acknowledges research support from the Institute of Government and Public Affairs, University of Illinois, and the Smith Richardson Foundation. Miller acknowledges financial assistance from the Australian Research Council. 


\author{
$\underline{\text { ABSTRACT }}$ \\ “WHY IS THE PAYOFF TO SCHOOLING SMALLER FOR IMMIGRANTS?” \\ Barry R. Chiswick \\ and \\ Paul W. Miller
}

To answer the question, this paper uses the Over-Required-Under Education technique, a new decomposition methodology and data on adult men from the 2000 US Census. Using the 510 three-digit occupational categories, similar patterns emerge whether the mean or mode of education in the occupation is used as the typical (required) level. The partial effect of the occupation's typical schooling level is the same for immigrants and natives. About two thirds of the smaller effect of schooling on earnings is attributable to differences by nativity in the payoffs to over/under education. The remainder is largely due to the different distributions by nativity of over/under education. Favorable immigrant selectivity, especially among the least skilled, and to a lesser extent, limited transferability of foreign schooling, is largely responsible for these patterns. A variety of tests of robustness are performed, including separate analyses for child and adult immigrants. (150 words) 
July 2007

Revised Nov. 2007, January 2008

\section{WHY IS THE PAYOFF TO SCHOOLING SMALLER FOR IMMIGRANTS?}

\section{INTRODUCTION}

One of the most striking empirical regularities that has emerged from comparative analyses of the earnings of immigrants and the native born is that the partial effect on earnings of a year of schooling is lower for the foreign born than for the native born. In Chiswick's (1978) seminal study, based on the 1970 US Census, the partial effect of a year of schooling on earnings for the native born was 7.2 percent, and that for the foreign born 5.7 percent.

This pattern has been repeated in analyses of the US labor market based on more recent data, and in analyses of other labor markets. For example, Baker and Benjamin (1994) report that the partial effect of years of schooling on earnings in the Canadian labor market was 7.3 percent for natives and 4.8 percent for immigrants in 1971, 6.6 percent and 4.4 percent, respectively, for these groups in 1981, and 7.6 percent and 4.9 percent, respectively, for the two groups in 1986.

For the Australian labor market in 1981, Beggs and Chapman (1988) report that the partial effect of schooling was 9.0 percent for the native born, 8.3 percent for immigrants from English-speaking countries, and only 4.9 percent for immigrants from non-English-speaking countries. Similarly, for the United Kingdom, Shields and Wheatley Price (1998) report that, in 1992-94, the partial effect of schooling was 6.9 percent for the white native born and 1.7 percent for non-white immigrants. These findings are not limited to English-speaking destinations. Similar findings emerge for Israel (see Chiswick (1979) and Friedberg (2000)) and Germany (Dustmann (1993)).

Three explanations for the lower partial effect of schooling among the foreign born are evaluated in this study: first, that it is due to self selection in migration that impacts mostly, though not exclusively, on the less-well educated; second, that it is due to the low degree of international skill transferability, a phenomenon that impacts mostly, 
though not exclusively, on the better educated; and thirdly, that it is due to discrimination in labor market earnings. ${ }^{1}$

The empirical relevance of these three explanations is assessed using insights from the overeducation/undereducation literature (see Hartog (2000), Daly et al. (2000) and Kiker et al. (1997)). It is reported in this literature that one-fifth to one-half of all workers may be in jobs that do not appear to be "well suited" to their schooling level. Some of these workers are "mismatched" because they have educational attainments below that which is typical for their jobs. These workers are undereducated, and it is argued below that their undereducated status (lower education given their occupation) is associated with self-selection in migration. Other workers may have educational attainments greater than that which is typical for their jobs. This is argued to arise from the less-than-perfect international transferability of human capital. Discrimination in labor market earnings is advanced in the conceptual framework presented as a potential cause of a smaller payoff to correctly-matched schooling for the foreign born. Separate analyses are conducted for immigrants who arrived in the US as young children and for those who arrived as adults.

The structure of the paper is as follows. Section II presents descriptive material on the extent of over- and under-education among immigrants in the United States, using data from the US 2000 Census of Population. It also outlines a model of the earnings determination process that is based on these concepts of over- and under-education. The empirical analysis in the subsequent sections is limited to males aged 25 to 64 years. The study of the payoff to education for women is an important topic, but it raises additional issues which are beyond the scope of the current paper. These include the labor supply decision, particularly among married women, and possibly differential selection in migration. Section III examines variations in earnings according to the match between the immigrants' educational attainments and the levels that are typical for their jobs. These analyses are conducted separately for the native born and the foreign born. Section

\footnotetext{
${ }^{1}$ A measurement error explanation would require this to be much more acute for immigrants from non-English-speaking countries than for those from English-speaking countries, and within the former group it needs to vary considerably by country of origin. This explanation cannot be pursued here directly because of the limited identifying instruments in the Census.
} 
IV then focuses on the extent to which the greater incidence of mismatch among the immigrant labor force can account for their lower partial effect of schooling. It develops a decomposition that is appropriate to the overeducation/undereducation conceptual framework. Section V conducts similar analyses among the foreign born for a number of birthplace groups, specifically, developed countries, less developed countries, and for specific birthplace regions within these two groupings. Section VI extends the analysis to consider the impact of schooling on the earnings of immigrants who came to the US as children and as adults. Section VII contains a summary and conclusion, with implications for the immigrant adjustment literature.

\section{OVER- AND UNDER-EDUCATION IN THE US IN 2000}

Each occupation can be viewed as having a "required", typical or reference level of education that is needed for satisfactory job performance. Within any occupation, however, there may be workers with levels of education greater than the reference level (“overeducated”) and less than this reference level (“undereducated”). ${ }^{2}$

The reference level of education has been determined in three ways in the overeducation/undereducation (ORU) literature, namely job analysis (Rumberger (1981)), worker self-assessment (Duncan and Hoffman (1981)) and realized matches (Verdugo and Verdugo (1989)). ${ }^{3}$ The realized matches method is the most amenable for use with Census data. This is based on the actual educational attainments of workers in each occupation.

Two alternatives have been used for realized matches based on the mean and the mode. Groot (1996) considers the mean and standard deviation of educational attainments within each occupation. Workers whose educational attainments are greater than one standard deviation above (below) the mean value for their occupation are categorized as “overeducated” (“undereducated”). An alternative, used here, merely uses deviations

\footnotetext{
${ }^{2}$ See McGuinness (2006) and Hartog (2000) for overviews of the theoretical frameworks consistent with the overducation/undereducation hypotheses.

${ }^{3}$ See Hartog (2000) for a review of this literature. The returns to education are apparently not sensitive to the measure used.
} 
from the mean. This is to avoid the problem raised by Hartog (2000, p.139) in using the mean plus/minus one standard deviation as the required level of schooling of the thresholds imposing a discrete jump for earnings at the tails of the distribution of overeducation and undereducation.

Cohn and Khan (1995) and Kiker et al. (1997), on the other hand, have preferred the use of the modal year of education in the worker's occupation in the realized matches procedure. When using the mode, workers whose educational attainments are greater than (less than) the modal value are categorized as “overeducated” (“undereducated”).

In this research the realized matches procedure will be used. Both the mode and the mean are used as the bases for the computations. The educational requirements of the jobs have been compiled using the educational attainment of all workers in each of the 510 three-digit occupations in the 2000 Census. ${ }^{4}$ Sensitivity tests indicate that the choice of population for defining the reference level of education is not a major issue.

Table 1 lists information from the 2000 US Census by country of birth on the modal level of schooling and on the distribution of the workforce across the three mutually exclusive and exhaustive categories of (i) correctly matched, (ii) overeducated, and (iii) undereducated workers. (Appendix A contains further details on the required education data, and Appendix B replicates Table 1 for the means, using plus/minus one standard deviation. ${ }^{5}$ The econometric analysis using means employs actual deviations from the means.)

The modal level of schooling for native-born males aged 25-64 is 12 years, as is that of the foreign born in the same age group. Using the realized matches method and the modal value for each person's occupation, around 33 percent of native-born male workers are overeducated, 24 percent undereducated, and 43 percent are correctly matched to their jobs. This is reasonably consistent with measures of the incidence of over- and under-education for the total US labor market presented in previous studies (Cohn and Khan (1995), Daly et al. (2000)).

\footnotetext{
${ }^{4}$ Given the overwhelming preponderance of the native born in nearly all occupations, the modal education is heavily influenced by their occupational distribution.

${ }^{5}$ The appendices in this paper are available from the authors upon request.
} 
Table 1

Modal Schooling Level and Incidence of Over- and Under-Education by Country of Birth, Males 25-64, 2000 U.S. Census

\begin{tabular}{|c|c|c|c|c|c|}
\hline & $\begin{array}{c}\text { Modal } \\
\text { Schooling } \\
\text { (years) }\end{array}$ & $\begin{array}{l}\text { Correctly } \\
\text { Matched } \\
\text { (percent) }\end{array}$ & $\begin{array}{l}\text { Overeducated } \\
\text { (percent) }\end{array}$ & $\begin{array}{l}\text { Undereducated } \\
\text { (percent) }\end{array}$ & $\begin{array}{l}\text { Sample } \\
\text { Size }\end{array}$ \\
\hline Native Born & 12.0 & 42.95 & 32.71 & 24.35 & 533,906 \\
\hline Foreign Born & 12.0 & 28.09 & 28.61 & 43.30 & 84,290 \\
\hline \multicolumn{6}{|l|}{ Region of Birth } \\
\hline Developed & 16.0 & 36.88 & 36.91 & 26.21 & 14,758 \\
\hline - United Kingdom & 16.0 & 38.55 & 37.31 & 24.14 & 1,737 \\
\hline - Ireland & 12.0 & 40.80 & 34.86 & 24.33 & 394 \\
\hline - Western Europe & 14.0 & 34.30 & 44.11 & 21.60 & 2,606 \\
\hline - Southern Europe & 12.0 & 35.17 & 24.07 & 40.76 & 3,328 \\
\hline - Eastern Europe & 12.0 & 38.09 & 40.13 & 21.78 & 1,880 \\
\hline - Former USSR & 16.0 & 32.85 & 50.79 & 16.36 & 1,649 \\
\hline - Canada & 16.0 & 40.13 & 35.65 & 24.23 & 1,985 \\
\hline - Australia \& NZ & 16.0 & 36.83 & 31.67 & 31.50 & 467 \\
\hline - Japan & 16.0 & 45.46 & 35.45 & 19.09 & 712 \\
\hline Less-Developed & 12.0 & 26.19 & 26.83 & 46.98 & 69,532 \\
\hline - Mexico & 5.5 & 17.18 & 10.76 & 72.05 & 27,757 \\
\hline - Cuba & 12.0 & 28.69 & 27.60 & 43.71 & 2,331 \\
\hline - Caribbean & 12.0 & 32.61 & 24.44 & 42.96 & 4,812 \\
\hline $\begin{array}{l}\text { - Central and South } \\
\text { America-Spanish }\end{array}$ & 12.0 & 26.68 & 24.88 & 48.44 & 10,023 \\
\hline $\begin{array}{l}\text { - Central and South } \\
\text { America-non } \\
\text { Spanish }\end{array}$ & 12.0 & 34.01 & 28.25 & 37.74 & 589 \\
\hline - Indochina & 14.0 & 33.91 & 27.06 & 39.03 & 3,730 \\
\hline - Philippines & 16.0 & 35.92 & 49.60 & 14.47 & 3,379 \\
\hline - China & 17.5 & 31.83 & 44.61 & 23.55 & 3,973 \\
\hline - South Asia & 16.0 & 34.01 & 53.22 & 12.77 & 4,264 \\
\hline - Other South Asia & 16.0 & 30.62 & 49.24 & 20.14 & 854 \\
\hline - Korea & 16.0 & 41.11 & 43.97 & 14.91 & 1,890 \\
\hline - Middle East & 16.0 & 31.97 & 47.13 & 20.90 & 3,436 \\
\hline - Sub Sahara Africa & 16.0 & 32.85 & 49.93 & 17.22 & 2,134 \\
\hline
\end{tabular}

Note: The modal level of schooling of each occupation is computed using information on all workers. See Appendix A for details. Correctly matched workers are defined as those with the modal years of education in their occupation.

Source: United States Census of Population, 2000, one percent sample, PUMS file.

While immigrants are as likely as the native born to be overeducated, the proportion undereducated differs sharply. Thus, 43 percent of foreign-born workers are undereducated and only 28 percent are correctly matched to the requirements of their 
jobs. ${ }^{6}$ The workers who are undereducated can be viewed as working in jobs that are above their measured schooling level. To the extent that they are able to perform these jobs, it implies that they have other unmeasured attributes, such as motivation, effort, apprenticeship or on-the-job training, that can compensate for their innate ability, measured schooling deficiency. Alternatively, there may be variability in skill requirements for jobs within the occupational categories that is correlated with the fraction foreign born.

Reflecting the fact that there is a distribution of educational attainments in each occupation, overeducated and undereducated workers are found in most of the 510 census occupations. However, the distribution is far from proportional to the representation of workers in each occupation, with around one-fifth of the native-born overeducated workers being in the following small number of jobs that typically have medium reference skill levels: (i) first-line supervisors/managers of retail sales workers or of production and operating workers; (ii) driver/sales workers; (iii) retail salespersons; (iv) carpenters; and (v) construction managers. The foreign-born overeducated are concentrated in similar occupations, though computer software engineers are a major addition to the list of occupations where foreign-born overeducated workers are prevalent.

Undereducation among the native born occurs disproportionately among the "all other managers group”, general/operating managers, chief executives, and sales representatives in wholesaling and manufacturing. Drivers and sales workers is distinguished by being an occupation which has many workers who are both undereducated and overeducated. This is because the occupational category is broad and covers a range of job tasks. Undereducated foreign-born workers tend to be in different occupations than the native born, with their main occupations being construction laborers, miscellaneous agricultural workers, ground maintenance workers, cooks and janitors/building cleaners.

\footnotetext{
${ }^{6}$ There is a much wider variance of schooling for the foreign born than for the native born. This, however, is largely reflecting the inter-country differences in schooling levels among immigrants.
} 
It is possible that the occupations where undereducated workers are concentrated do not actually require the level of education which is typical among incumbents, and this is why, as shown below, those with fewer years of schooling can perform satisfactorily in these occupations. However, the fact that the patterns that emerge from the realized matches method for establishing job requirements are remarkably similar to those reported based on the objective assessments under the job analysis procedure, or those for worker assessments (Hartog (2000)), suggests that there is a meaningful distinction to be made between those who are undereducated and those who are correctly matched to the education requirements of their jobs.

There are also noticeable variations in the extent of overeducation and undereducation across birthplace regions (Table 1). Immigrants with a high modal level of schooling are generally characterized by a high incidence of overeducation, while those with a low modal level of schooling have a high incidence of undereducation. The simple correlation coefficient between the modal level of education and the incidence of overeducation for the birthplace regions in Table 1 is 0.796 , while for undereducation it is -0.851, and for the correct matching it is much lower, 0.576 . $^{7}$

This analysis was repeated using the mean level of education in each occupation as the benchmark. Relevant details are reported in Appendix B. The salient features of this analysis appear to be insensitive to the underlying methodology, of mode or mean, as the measure of the match.

When examining the consequences for earnings of overeducation and undereducation, researchers have made use of a variant of the human capital earnings function that has been termed the ORU (Overeducation/Required education/Undereducation) specification. In this model, the dependent variable is the natural logarithm of earnings $\left(\ln Y_{i}\right)$ and the variable for actual years of education is decomposed into three terms. That is,

$$
\ln Y_{i}=\alpha_{0}+\alpha_{1} \text { Over_Educ }_{i}+\alpha_{2} \text { Req_Educ }_{i}+\alpha_{3} \text { Under_Educ }_{i}+\ldots+u_{i}
$$

where

Over_Educ = years of surplus education or overeducation

\footnotetext{
${ }^{7}$ More extensive analyses of the incidence of overeducation, undereducation and of correctly matched education are reported in Chiswick and Miller (2007).
} 
Req_Educ = required or reference years of education

Under_Educ $=$ years of deficit education or under education

and the actual years of education equals Over_Educ + Req_Educ - Under_Educ. Note that for each individual, "Over_Educ" and "Under_Educ" cannot both be positive. Either one or both must be zero.

\section{EARNINGS AND JOB MATCHING}

Table 2 presents the results for the education variables from the regression analysis of earnings for employed adult men in the United States. (The full regression is reported in Appendix C.) The table contains estimates for both the native and the foreign born. Columns (i) and (iv) provide the results based on the standard model, while columns (ii) and (v) give the results generated by the ORU model. For both the standard and ORU models, a set of non-education explanatory (control) variables is entered into the specification. The change from the standard to the ORU specification of education has no major effect on the coefficients of the control variables (see Appendix C). All of the equations are estimated using OLS, with heteroskedasticity-consistent standard errors. $^{8}$

For the native born, according to Table 2, column (i), the return to an additional year of education is 10.6 percent. $^{9}$ This is slightly higher than has been reported from analyses of earlier data sets, though it represents a continuation of the increase in the partial effect of schooling recorded in recent decades. Among the foreign born, the partial effect of years of schooling on earnings is only 5.2 percent. This is only one-half the effect found for the native born and the difference in estimated effects is highly significant. Thus the pattern observed by Chiswick (1978), based on analyses of the 1970

\footnotetext{
${ }^{8}$ It is possible that the educational attainment and ORU variables are endogenous in the model of earnings, though analysis of this is prevented by the absence of suitable instruments in the census data. This approach is standard in the human capital literature in general, including the undereducation/overeducation literature.

${ }^{9}$ The conventional interpretation of the coefficient on the education variable as the approximate return to an additional year of education is used here. See Chiswick (2003) for discussion.
} 
Census, and found in later Censuses and for other countries, is alive and well three decades later.

Table 2

Coefficients on the Education Variables from a Regression Analysis of Earnings, US 2000 ${ }^{(a)}$

\begin{tabular}{|c|c|c|c|c|c|c|}
\hline \multirow[b]{2}{*}{ Variable } & \multicolumn{3}{|c|}{ Native Born } & \multicolumn{3}{|c|}{ Foreign Born } \\
\hline & (i) & (ii) & Mean/(SD) & (iv) & (v) & Mean/(SD) \\
\hline Actual Education & $\begin{array}{c}0.106 \\
(202.11)\end{array}$ & (c) & $\begin{array}{l}13.67 \\
(2.51)\end{array}$ & $\begin{array}{c}0.052 \\
(66.51)\end{array}$ & (c) & $\begin{array}{l}11.874 \\
(4.78)\end{array}$ \\
\hline Reference Education ${ }^{(\mathrm{b})}$ & (c) & $\begin{array}{c}0.154 \\
(254.62)\end{array}$ & $\begin{array}{l}13.57 \\
(1.98)\end{array}$ & (c) & $\begin{array}{c}0.153 \\
(91.66)\end{array}$ & $\begin{array}{l}13.25 \\
(1.94)\end{array}$ \\
\hline Overeducation & (c) & $\begin{array}{c}0.056 \\
(52.26)\end{array}$ & $\begin{array}{c}0.70 \\
(1.21)\end{array}$ & (c) & $\begin{array}{c}0.044 \\
(18.41)\end{array}$ & $\begin{array}{c}0.71 \\
(1.35)\end{array}$ \\
\hline Undereducation & (c) & $\begin{array}{l}-0.067 \\
(69.42)\end{array}$ & $\begin{array}{c}0.61 \\
(1.39)\end{array}$ & (c) & $\begin{array}{c}-0.021 \\
(21.30)\end{array}$ & $\begin{array}{c}2.08 \\
(3.39)\end{array}$ \\
\hline
\end{tabular}

Notes:

(a) Partial effects of the education variable from a regression of the natural logarithm of earnings in 1999 on education and labor market experience, weeks worked, married, veteran, race, English language proficiency, living in the South and in metropolitan area, and for the foreign born, years since migration and US citizen. Full regression equation in Appendix C.

(b) Based on Realized Matching approach using the mode.

(c) Variable not entered.

Source: United States Census of Population, 2000, one percent sample, PUMS file.

Table 2, Columns (ii) and (v) list the results from the ORU model. The $\bar{R}^{2}$ for this model is 0.357 for the native born and 0.404 for the foreign born. Hence the change in the specification of the education variable is associated with an increase in the adjusted $\bar{R}^{2}$ of between two and four percentage points. This compares favorably with the increase of only one percentage point (or less than 2 percent of the unexplained variation) following the inclusion of the country of birth fixed effects in the analyses for the foreign born. This suggests that the ORU specification of the education variable has considerable relative explanatory capability. ${ }^{10}$

${ }^{10}$ By setting $\alpha_{1}=\alpha_{2}=\left(-\alpha_{3}\right)$ in the ORU model of equation (1), the traditional earnings function is obtained. This set of restrictions is rejected by the data, lending formal statistical support to the ORU model. Hartog (2000, p.135) concludes that this superiority of the ORU specification is not testimony of a non-linearity in the returns to education, as 
For the native born (Table 2, column (ii)), the return on the reference years of education is 15.4 percent, almost five percentage points higher than that obtained when the actual years of education variable is used in the specification. The return to the reference years of education for the foreign born is 15.3 percent, which is almost identical to the return for the native born. The return to the reference years of education is a return to having the extra year of education and being placed in an occupation where the education is typical. Thus, there are two changes, the person's education and his occupation. Once "mismatches" are taken into account, the return to years of schooling is higher than otherwise.

There are two types of mismatches: overeducation and undereducation. Among the native born, years of overeducation are associated with 5.6 percent higher earnings. That is, a year of correctly matched education is associated with 15 percent higher earnings, but a year of education beyond that which is typical for the worker's occupation is associated with only 5.6 percent higher earnings. To put it in context, the cab driver with a BA earns more than the high school graduate cab driver, but the return on the extra four years of schooling is very low. As shown in Table 1, 32.7 percent of native-born workers are overeducated. The overeducated native-born workers have, on average, 2.13 years of surplus education.

Among the foreign born, a year of overeducation is associated with only 4.4 percent higher earnings. This is one percentage point less than the earnings increment associated with overeducation for the native born, and this difference is statistically significant (' $t$ ' statistic on the difference is 4.62). According to Table 1, 28.6 percent of the foreign born are overeducated. Overeducated immigrants have, on average, 2.48 years of overeducation.

Years of undereducation are associated with an earnings penalty of 6.7 percent among the native born, and an earnings penalty of only 2.1 percent among the foreign born. The difference between these estimates is highly significant ('t' statistic $=33.11$ ). These earnings penalties impact on a major segment of the workforce. Among the

the education mismatch effects carry over to models that include a squared education variable. This finding carries across to the current analysis. 
native-born workforce, 24.3 percent is undereducated (Table 1), and the mean years of undereducation among them is 2.5. Among the foreign born the incidence of undereducation is much larger, at 43.3 percent (Table 1), and the mean years of undereducation is also much larger, it is 4.8 .

These estimates of the returns to the reference years of education, years of overeducation and years of undereducation are not sensitive to the way the reference years of education have been computed. To illustrate this, the ORU model was estimated with the reference years of education being computed using information only for nativeborn workers, and also using information only for native-born male workers. The reference years of education were also computed using only 23 broad occupational categories in place of the 510 detailed census occupations used for Table 2. Selected results are presented in Table 3. These results are perhaps not surprising given the very high correlation among these alternative ways for defining the reference years of education. The literature does not provide a basis for choosing among the algorithms used in Table 3, although the use of all occupations rather than the 23 broad categories is better suited for a job matching model.

Table 3

Estimated Coefficients for Education Variables in ORU Model with Different Reference Levels of Education ${ }^{(a)}$

\begin{tabular}{|lcccc|}
\hline & \multicolumn{4}{c|}{ Reference Level of Education } \\
\cline { 2 - 5 } Variable & $\begin{array}{c}\text { All Workers } \\
\text { (i) }\end{array}$ & $\begin{array}{c}\text { Native-born } \\
\text { Workers } \\
\text { (ii) }\end{array}$ & $\begin{array}{c}\text { Native-born } \\
\text { Male Workers } \\
\text { (iii) }\end{array}$ & $\begin{array}{c}\text { All Workers, } \\
\text { 23 Occupations } \\
\text { (iv) }\end{array}$ \\
\hline $\begin{array}{lcccc}\text { 1. Native born } \\
\text { Reference }\end{array}$ & 0.154 & 0.154 & 0.149 & 0.141 \\
Education & $(254.62)$ & $(254.71)$ & $(246.89)$ & $(221.34)$ \\
Overeducation & 0.056 & 0.057 & 0.050 & 0.093 \\
& $(52.26)$ & $(53.85)$ & $(42.72)$ & $(101.44)$ \\
Undereducation & -0.067 & -0.067 & -0.072 & -0.074 \\
& $(69.42)$ & $(69.04)$ & $(77.29)$ & $(72.76)$ \\
$\bar{R}^{2}$ & 0.3565 & 0.3566 & 0.3539 & 0.3445 \\
& & & & \\
2. Foreign Born & & & & \\
Reference & 0.153 & 0.152 & 0.137 & 0.149 \\
Education & $(91.66)$ & $(91.27)$ & $(82.08)$ & $(84.85)$ \\
Overeducation & 0.044 & 0.044 & 0.044 & 0.074 \\
\hline
\end{tabular}




\begin{tabular}{|lllll|}
\hline & $(18.41)$ & $(18.72)$ & $(17.40)$ & $(33.66)$ \\
Undereducation & -0.021 & -0.022 & -0.025 & -0.020 \\
& $(21.30)$ & $(21.78)$ & $(24.70)$ & $(20.31)$ \\
$\bar{R}^{2}$ & 0.4040 & 0.4034 & 0.3948 & 0.3963 \\
\hline
\end{tabular}

Notes: (i) The reference level of education is based on the educational attainments of all workers in the 510 Census occupations.

(ii) The reference level of education is based on the educational attainments of native-born workers in the 510 Census occupations.

(iii) The reference level of education is based on the educational attainments of native-born male workers in the 510 Census occupations.

(iv) The reference level of education is based on the educational attainments of all workers in 23 broad Census occupational categories.

(a) Heteroscedasticity consistent "t" statistics in parentheses.

Source: United States Census of Population, 2000, one percent sample, PUMS file.

Similarly, the estimates of the earnings effects of overeducation and undereducation are not sensitive to the linearity assumption of Table 2 with respect to the payoff to the typical years of schooling. ${ }^{11}$ Hence, when the square of the reference level of education was included in the model, the results for the ORU variables among the native born were:

$$
\begin{aligned}
& \text { 0.325Req_Educ }-0.006 \text { Req_Educ }{ }^{2}+0.056 \text { Over_Educ }-0.069 \text { Under_Educ } \\
& \begin{array}{lll}
(29.12) & (15.29)
\end{array}
\end{aligned}
$$

For the foreign born, the estimates for the ORU variables in the more general specification were:

$$
\begin{aligned}
& \text { 0.496Req_Educ }-0.012 \text { Req_Educ }{ }^{2}+0.042 \text { Over_Educ }-0.021 \text { Under_Educ } \\
& (20.11) \\
& (13.87)
\end{aligned}
$$

Comparing these results to those in Table 2, there is little change in the overeducation or the undereducation coefficients. Under the quadratic specification for the reference level of education, the payoff to correctly matched education for the foreign

\footnotetext{
${ }^{11}$ The finding of lower returns to schooling for the foreign born than for the native born is also not sensitive to the linearity assumption of Table 2. When the actual years of education are entered into the model in quadratic form, the coefficients on the linear and squared terms were -0.0283 and 0.005 , respectively, for the native born, and -0.0544 and 0.0053 , respectively, for the foreign born. Thus, evaluated at 8, 12 and 16 years of schooling, the payoff to schooling is $5.24,9.27$ and 13.30 percent for the native born, and 2.97, 5.08 and 11.39 percent for the foreign born.
} 
born is greater than that for the native born up to 14 years of education, and is less than that for the native born beyond that level.

Patterns similar to those in Table 2 are found when the mean rather than the mode is used as the required level of education (Appendix D). In the regression analyses of means the number of years of over/under education is computed as the difference between the respondent's schooling and the mean schooling level in his occupation. The coefficient on required education is 16.7 percent for the native born (an increase from 10.6 percent for education), and 15.7 percent for the foreign born (an increase from 5.2 percent). The coefficients on years of overeducation are close, 5.1 percent and 4.1 percent, respectively, for the native born and foreign born. There is divergence in the coefficients for undereducation, -5.2 percent for the native born and -1.3 percent for the foreign born.

The significance of the Table 2 estimates is easily seen with the aid of an example. Consider five types of workers as described in Table 4. For this illustration, the annual earnings of the Type B workers have been set to $\$ 30,000$ among both the native born and the foreign born. Then, compared to these Type B workers, the Type A workers have two fewer years of required education. With an education coefficient of 15.4 percent for the native born and 15.3 percent for the foreign born, their mean annual earnings will be around \$22,049 for the native born, and \$22,093 for the foreign born. ${ }^{12}$ The Type C workers, with two extra years of required education compared to the Type B workers, will have mean annual earnings of around $\$ 40,823$ and $\$ 40,741$ for the native born and foreign born, respectively. ${ }^{13}$

\footnotetext{
${ }^{12}$ As $\log (30000)=10.309$, these figures are computed as exp $(10.309-2 * 0.154)$ and exp (10.309 - 2*0.153), respectively.

${ }^{13}=\exp (10.309+2 * 0.154)$ and $\exp (10.309+2 * 0.153)$, respectively.
} 


\section{Table 4}

Earnings of Hypothetical Workers

\begin{tabular}{|c|c|c|c|c|c|}
\hline \multirow{2}{*}{$\begin{array}{l}\text { Worker } \\
\text { type }\end{array}$} & \multirow{2}{*}{$\begin{array}{c}\text { Actual Years } \\
\text { of } \\
\text { Education }\end{array}$} & \multirow{2}{*}{$\begin{array}{c}\text { Reference Years } \\
\text { of } \\
\text { Education } \\
\end{array}$} & \multirow{2}{*}{$\begin{array}{c}\text { ORU } \\
\text { Classification }\end{array}$} & \multicolumn{2}{|c|}{ Hypothetical Earnings } \\
\hline & & & & $\begin{array}{l}\text { Native } \\
\text { Born }\end{array}$ & $\begin{array}{c}\text { Foreign } \\
\text { Born }\end{array}$ \\
\hline A & 10 & 10 & Correct Match & 22,049 & 22,093 \\
\hline B & 12 & 12 & Correct Match & 30,000 & 30,000 \\
\hline $\mathrm{C}$ & 14 & 14 & Correct Match & 40,823 & 40,741 \\
\hline $\mathrm{D}$ & 10 & 12 & Undereducated & 26,239 & 28,767 \\
\hline $\mathrm{E}$ & 14 & 12 & Overeducated & 33,557 & 32,761 \\
\hline
\end{tabular}

Type D workers differ from Type B workers by having two fewer years of actual education. That is, they are undereducated by two years. Hence Type D workers will have mean annual earnings around \$26,239 if native born (education coefficient of minus 6.7 percent) and \$28,767 if foreign born (education coefficient of minus 2.1 percent). ${ }^{14}$

Type E workers differ from Type B workers by having two extra years of actual education. They have the same number of years of required education. Hence, they are overeducated by two years. They will have mean earnings of \$33,557 if native born, and $\$ 32,761$ if foreign born (education coefficients of 5.6 percent and 4.4 percent, respectively). ${ }^{15}$

Figure 1 portrays the earnings of these five types of workers. It illustrates the distinctive patterns from the ORU literature and shows how immigrants and the native born appear to differ in important ways in the earnings effects associated with mismatched education. This figure has been constructed to depict the fact that undereducation is generally a characteristic among individuals with low education levels, while overeducation is generally a characteristic among individuals with high education levels. It has three features.

\footnotetext{
${ }^{14}=\exp (10.309-2 * 0.067)$, and $\exp (10.309-2 * 0.021)$ respectively.

${ }^{15}=\exp (10.309+2 * 0.056)$, and $\exp (10.309+2 * 0.044)$ respectively.
} 


\section{Figure 1}

\section{Earnings Situations of Hypothetical Workers}

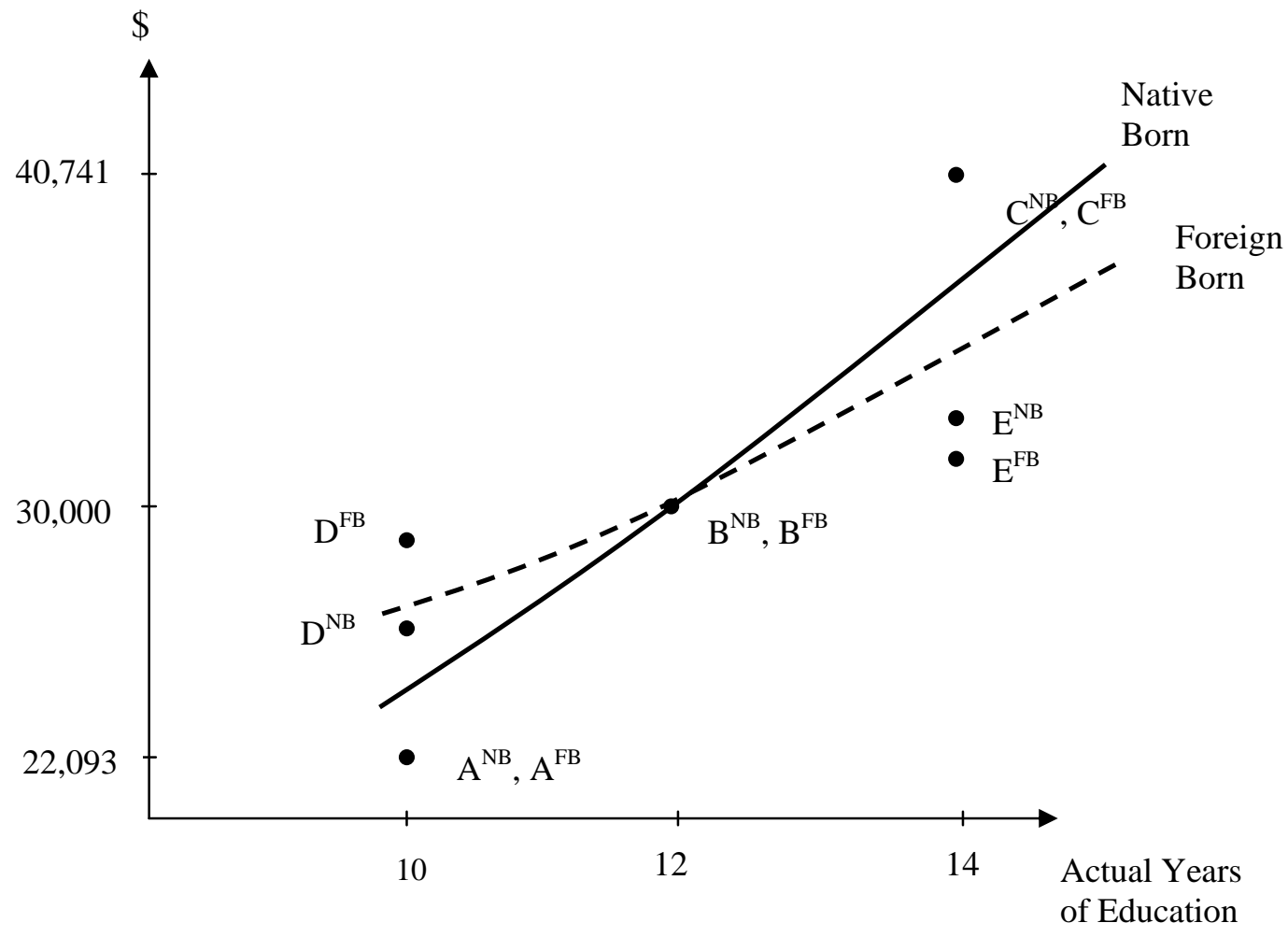

First, there are sizeable earnings increments to correctly matched education (compare workers of Types A, B and C). These increments are essentially the same for the native born and foreign born, though if the Table 3, column (iii) estimates were used in preference to the Table 3, column (i) data, the increments would be slightly less for immigrants than for the native born.

Second, the Type D workers, with 10 years of education, but working in an occupation that requires 12 years of education, earn more than workers who have 10 years of education and work in an occupation that requires 10 years of education (Type A), but they earn less than those with whom they share an occupation who have the correct (12 years) level of education for that occupation (Type C). The undereducated from both birthplace groups are associated with relatively high earnings compared with those with the same level of education who are correctly matched. This earnings advantage is presumably associated with unobservables that the undereducated are 
disproportionately endowed with that enable them to be employed in the higher-level occupation.

Note that the undereducated foreign born do better than the undereducated native born. This is consistent with Chiswick's $(1978,1999)$ motivation/ability hypothesis which proposes that the foreign born at the lower levels of education are more favorably selected on the basis of ability/motivation than the better educated foreign born, and as such also possess higher mean levels of these unobserved productivity enhancing characteristics than do the less educated native born.

Third, the Type E workers, with 14 years of education who work in an occupation that requires only 12 years of education, earn more than the workers with whom they share an occupation who have the correct level of education for that occupation (Type B), but they earn far less than workers with 14 years of education who are correctly matched in an occupation (Type C). The earnings disadvantage for these overeducated workers is greater for the foreign born than for the native born, and this can be linked to the lessthan-perfect international transferability of skills possessed by the foreign born. ${ }^{16}$

The return to reference years of education is given by the slope of the line through points A, B and C. In comparison, the return to actual years of education will be derived from earnings-years of education relationships based on averages of the earnings for the workers described above at each level of education (e.g., average for Type A and Type D workers at 10 years of education, average for Type $\mathrm{C}$ and Type $\mathrm{E}$ workers at 14 years of education). This will, therefore, depend on both the estimated earnings effects associated with mismatched education, and the number of workers in each education category. As the estimated earnings of undereducated workers are above those for correctly matched workers, and the estimated earnings of overeducated workers are below those for correctly matched workers, the return to actual years of education will be lower than the return to reference years of education.

The differences between the native born and the foreign born in the earnings effects associated with undereducation and overeducation depicted in Figure 1, and the disparities in the representations of the birthplace groups in these categories (shown in

\footnotetext{
${ }^{16}$ The issue of skill transferability is less relevant for those with low levels of skill. In the extreme, if there is no skill, skill transferability is not an issue.
} 
Table 5 below), are consistent with a lower estimate of the return to actual years of education for the foreign born than for the native born.

Given the size of the earnings effects of overeducation and undereducation for the foreign born and the native born, and the relative importance of the two types of mismatch for each birthplace group, the framework developed here also suggests that the lower payoff to schooling is due much more to the undereducation phenomenon (associated with positive selection in immigration in the literature) than with overeducation (associated with the less-than-perfect international transferability of skills). This contrasts with the apparent importance of the less-than-perfect transferability of skills in studies such as Jasso et al. (2002) and Beggs and Chapman (1988). ${ }^{17}$ The decomposition developed below allows the quantification of the separate contributions of undereducation and overeducation to the lower payoff to schooling for the foreign born.

\section{THE PAYOFF TO SCHOOLING AMONG IMMIGRANTS}

The presentation of the earnings consequences of overeducation and undereducation in Figure 1 suggests that the keys to understanding why there is a smaller partial effect of actual years of schooling on earnings among the foreign born compared to the native born are: (i) the earnings increments associated with discrepancies between workers' actual years of education and the level of education that is typical in their jobs; (ii) the distributions of overeducation and undereducation at each level of schooling for the foreign born and the native born; and (iii) the distributions of workers across the actual years of schooling categories.

In terms of (i) above, it has been noted above that foreign-born workers who are undereducated have higher earnings relative to other immigrants with the typical level of education than is the situation for the native born. In the case of overeducation, the foreign born have smaller gains associated with "surplus" education than the native born.

\footnotetext{
${ }^{17}$ Jasso et al. (2002) show, based on study of post-arrival earnings, controlling for prearrival earnings, that perhaps only around one-third of immigrants' human capital skills are internationally transferable. A more optimistic picture is presented in Chiswick, Lee and Miller (2005), although this study is based on occupational status scores, and does not capture worker mobility within an occupation.
} 
Both of these patterns will lead to a smaller payoff to schooling for immigrants than for the native born (see Figure 1).

Point (iii) above is important to understanding the difference in the payoff to schooling between the native born and foreign born because of the pronounced differences between these groups in the distributions across education categories. This is illustrated in Table 5.

The foreign born have a greater variance in schooling, with the main difference in actual years of education between the two birthplace groups occurring among the lesswell-educated. Thus, while 3 percent of the native born have 9 or fewer years of education, 25 percent of the foreign born are in this education category. Among the better educated, however, the proportional representations of the native born and foreign born are reasonably similar. Thus, 19 percent of the native born have exactly 16 years of schooling, and a further 11 percent have 17 or more years of schooling. Among the foreign born, the percentages are 14 and 13 percent, respectively.

Note that conditional upon a particular actual years of education, there are only modest differences between the native born and the foreign born in the extent of undereducation. The differences in the extent of overeducation between the native born and foreign born are also minor. For example, among those with 16 or 17 or more years of education, native-born workers are slightly more likely to have one or two years of surplus education than are the foreign born, but are less likely than the foreign born to have three or more years of surplus education. We return to this issue below in relation to Table 6.

Table 5

Distribution (\%) of Workers Across Years of Overeducation and Undereducation by Years of Actual Education ${ }^{(a)}$

\begin{tabular}{|c|c|c|c|c|c|c|c|}
\hline \multirow{2}{*}{$\begin{array}{l}\text { Actual Years } \\
\text { of Education }\end{array}$} & \multirow{2}{*}{$\begin{array}{c}\% \text { of } \\
\text { Workers }\end{array}$} & \multicolumn{2}{|c|}{$\begin{array}{c}\text { Years of } \\
\text { Undereducation }\end{array}$} & \multicolumn{4}{|c|}{$\begin{array}{c}\text { Years of } \\
\text { Overeducation }\end{array}$} \\
\hline & & $3+$ & $1-2$ & 0 & $1-2$ & $3+$ & Total \\
\hline 1. Native Borr & & & & & & & \\
\hline $\begin{array}{l}9 \text { or fewer } \\
10-11\end{array}$ & $\begin{array}{l}3.26 \\
4.56\end{array}$ & $\begin{array}{c}100.00 \\
7.41\end{array}$ & $\begin{array}{c}0.00 \\
92.59\end{array}$ & $\begin{array}{l}0.00 \\
0.00\end{array}$ & $\begin{array}{l}0.00 \\
0.00\end{array}$ & $\begin{array}{l}0.00 \\
0.00\end{array}$ & $\begin{array}{l}100.00 \\
100.00\end{array}$ \\
\hline 12 & 39.17 & 10.28 & 15.57 & 61.33 & 12.81 & 0.00 & 100.00 \\
\hline 14 & 23.29 & 0.95 & 23.45 & 19.85 & 55.75 & 0.00 & 100.00 \\
\hline 16 & 19.22 & 0.53 & 2.71 & 59.53 & 15.21 & 22.03 & 100.00 \\
\hline
\end{tabular}




\begin{tabular}{|lccccccc|}
$17^{+}$ & 10.50 & 0.38 & 0.52 & 27.22 & 43.90 & 27.98 & 100.00 \\
Total & 100.00 & 7.99 & 16.36 & 42.95 & 25.53 & 7.17 & 100.00 \\
& & & & & & & \\
2. Foreign Born & & & & & & & \\
9 or fewer & 25.00 & 100.00 & 0.00 & 0.00 & 0.00 & 0.00 & 100.00 \\
$10-11$ & 4.88 & 7.81 & 92.19 & 0.00 & 0.00 & 0.00 & 100.00 \\
12 & 27.82 & 8.61 & 26.39 & 55.08 & 9.91 & 0.00 & 100.00 \\
14 & 14.54 & 0.85 & 19.82 & 18.32 & 61.01 & 0.00 & 100.00 \\
16 & 14.43 & 0.71 & 2.49 & 51.97 & 14.71 & 30.11 & 100.00 \\
$17^{+}$ & 13.34 & 0.72 & 0.95 & 19.49 & 39.85 & 38.99 & 100.00 \\
Total & 100.00 & 28.10 & 15.21 & 28.09 & 19.07 & 9.55 & 100.00 \\
\hline
\end{tabular}

Note: (a) Rows and Columns may not sum to 100.00 due to rounding; in constructing the table, individuals with either 11.5 or 12.5 years of actual education have been included in the "12 years" category, and all half-years of overeducation and undereducation have been rounded up.

Source: United States Census of Population, 2000, one percent sample, PUMS file.

The implication of this overeducation and undereducation for the payoff to schooling for the foreign born can be demonstrated as follows.

First, for each of the fifteen educational attainments listed in Appendix A, a hypothetical mean earnings was constructed assuming:

i. the workers at each educational attainment had the distribution across the undereducation, overeducation and typical education categories specific to the foreign born at the particular education level;

ii. the workers had the sample (across all levels of education) mean levels of all other characteristics that were included in the earnings equations in Table 2. This standardizes for variations in these characteristics across levels of education;

iii. the workers had a payoff to each characteristic given by the estimates for the total foreign-born sample, as per the full regression equation in Appendix C.

A linear regression was then computed, relating these mean predictions of log earnings at each level of education to the education levels. This regression was weighted by the numbers in each education category. The return to schooling computed under this exercise was 5.3 percent, which mirrors the payoff to schooling of 5.2 percent in column (iv) of Table $2 .^{18}$

${ }^{18}$ A similar set of calculations for the native born yielded a payoff to their schooling of 10.5 percent, which mirrors the payoff reported in Table 2. 
Second, in forming the predictions, the effects associated with overeducation, undereducation and correctly matched education for the foreign born, of 4.4 percent, -2.1 percent and 15.3 percent, respectively, were replaced by the respective effects for the native born, of 5.6 percent, -6.7 percent and 15.4 percent. This effectively assigns a foreign-born undereducated worker such as $\mathrm{D}^{\mathrm{FB}}$ in Figure 1 an earnings level of $\mathrm{D}^{\mathrm{NB}}$ in the same figure, and it assigns a foreign-born overeducated worker such as $\mathrm{E}^{\mathrm{FB}}$ in Figure 1 an earnings level of $\mathrm{E}^{\mathrm{NB}}$. A weighted linear regression was then computed, relating these predictions to the level of education. The payoff to schooling was found to be 8.5 percent. This is an estimate of the effect of actual years of schooling on earnings under the condition that the earnings effects associated with overeducation and undereducation for the foreign born - or the conditions that gave rise to these earnings effects - are the same as for the native born.

Third, the predictions were computed replacing the information on the distribution of the foreign born across the overeducation and undereducation categories at each level of schooling by the data on overeducation and undereducation at the comparable levels of schooling for the native born. The purpose of this set of predictions is to ascertain the contribution at each level of schooling, for the foreign born and the native born, that the different levels of overeducation and undereducation make to the lower payoff to schooling for the foreign born. This results in a further, though much more modest, increase in the payoff to schooling for the foreign born, to 8.6 percent. The reason for the minor incremental change is that, conditional on the most detailed information on level of education available (see Appendix A), there are only minor differences between the distributions of the foreign born and native born across the overeducation, required education and undereducation categories.

Fourth, the previous set of predictions, which set the earnings effects of overeducation and undereducation for the foreign born to be the same as for the native born, and also set the distribution across overeducation/undereducation categories for the foreign born at each level of actual schooling to be the same as for the native born, were related to actual years of education in a linear regression using the distribution of the 
native born across education levels as weights. ${ }^{19}$ As much of the overall differences in overeducation/undereducation come about because the foreign born have, on average, a lower level of education than the native born, using the distribution of the native born across education levels will effectively assign the foreign born the same overall levels of overeducation and undereducation as the native born. As expected, this simulation resulted in a payoff to schooling for the foreign born that is the same as that for the native born. Table 6, Panel A, summarizes the results of these simulations.

In summary, 3.2 percentage points or approximately 62 percent of the difference in the payoffs to schooling for the foreign born and native born appears to be due to the differences between these birthplace groups in the partial effects on earnings associated with overeducation and undereducation. Only 0.1 percentage points (three percent) is due to different distributions of workers across overeducation/undereducation categories, conditional upon the actual level of education. Finally, 1.9 percentage points (36 percent) is due to the disproportionate representation of the foreign born among the lower education categories where undereducation, which tends to flatten the earnings-education gradient, is more prevalent.

\section{Table 6}

Implied Payoffs to Schooling, Adjusting for Over- and Under-Education

\begin{tabular}{|lc|}
\hline (A) Adjusted for over- and undereducation & \% Payoff \\
Native Born & 10.5 \\
Foreign Born & 5.3 \\
- no adjustment \\
(a) assuming same earnings effects to overeducation and \\
$\quad$ undereducation as native born \\
(b) as for (a) but also same levels of overeducation and \\
$\quad$ undereducation within each schooling category as native \\
$\quad$ born \\
(c) as for (b) but also assuming same distribution across \\
$\quad$ schooling categories for the foreign born as for the native \\
born
\end{tabular}

19 The adjustment for the distribution of overeducation and undereducation at each schooling category adjusts for a conditional (on the distribution of years of actual education) distribution of overeducation and undereducation. The application of the weights outlined here facilitates an adjustment for the unconditional distribution of overeducation and undereducation. 


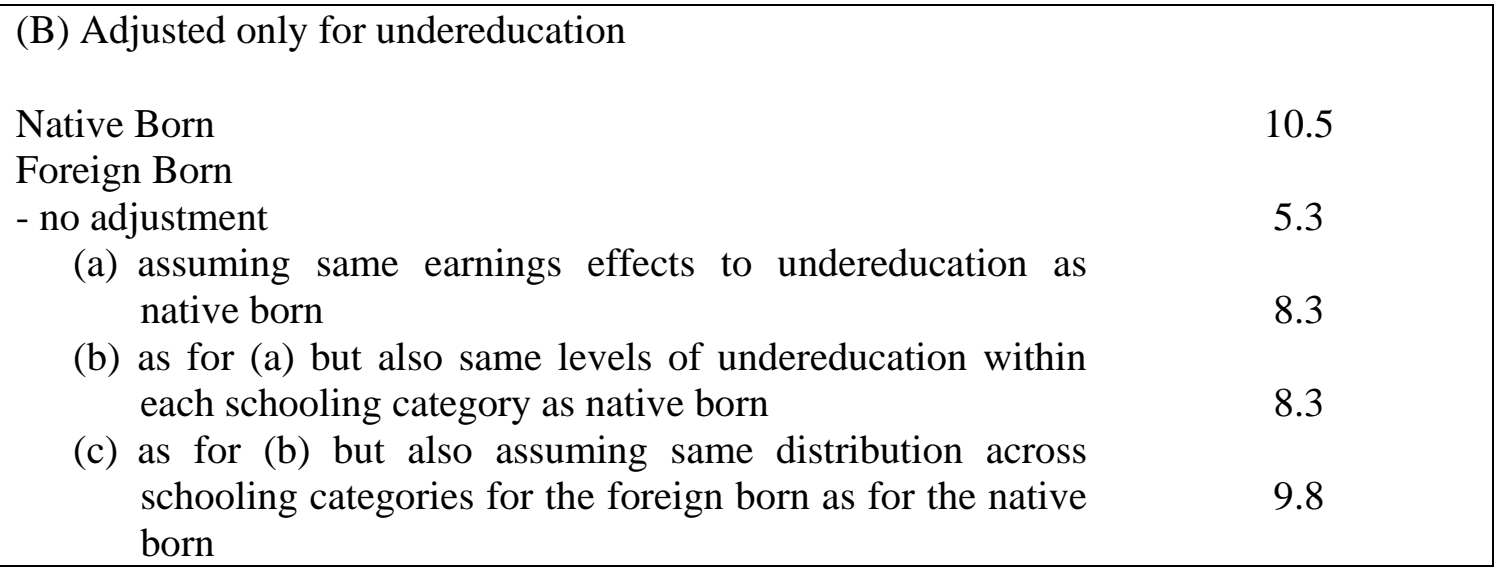

Source: Authors' calculations.

The computations above adjust for the effects of both overeducation (which has been linked to the less-than-perfect international transferability of human capital) and undereducation (which has been linked to positive self selection in immigration). The relative contributions that these types of mismatch make to the lower payoff to schooling for the foreign born can be established by repeating the calculations for Panel A of Table 6 with adjustment for only one type of mismatch.

Panel B in Table 6 presents results where adjustments in the decomposition are made only for undereducation. The percent payoff figures in Panel B are very close to those in Panel A, where adjustment was made for both undereducation and overeducation. It is quite clear, therefore, that almost all the gap between the payoff to schooling for the foreign born and the native born is due to the earnings effects associated with undereducation, and the different distributions of the two birthplace groups across the schooling categories that leads to the foreign born being disproportionately represented among the undereducated categories. In other words, the lower payoff to schooling for the foreign born appears to be driven largely by the consequences of the positive selection in immigration, in particular among immigrants with low levels of schooling.

\section{ANALYSES FOR BIRTHPLACE GROUPS}

Given the apparent strength of the findings above on the source of the lower payoff to schooling for the foreign born, it is of interest to carry the decomposition over 
to separate birthplace groups within the foreign born aggregate. Conducting the decompositions for these separate birthplaces will test the robustness of the findings.

Table 7 presents estimates of the relationship between the natural logarithm of earnings and actual years of education (column i), and another regression between the natural logarithm of earnings and reference years of education, years of overeducation and years of undereducation (columns ii to iv) for the major birthplace regions considered previously.

Table 7

Partial Effects of Education on Earnings, Foreign-born Adult Men in Paid Employment, Over/Under Education Based on Modal Education, by Birthplace, U.S. $2000^{(a)}$

\begin{tabular}{|c|c|c|c|c|c|}
\hline Birthplace & $\begin{array}{c}\text { (i) } \\
\text { Actual } \\
\text { Education }\end{array}$ & $\begin{array}{c}\text { (ii) } \\
\text { Reference } \\
\text { Education }^{\left({ }^{)}\right)}\end{array}$ & $\begin{array}{c}\text { (iii) } \\
\text { Over } \\
\text { Education }\end{array}$ & $\begin{array}{c}\text { (iv) } \\
\text { Under } \\
\text { Education }\end{array}$ & $\begin{array}{c}(\mathrm{v}) \\
\text { Sample } \\
\text { size }\end{array}$ \\
\hline$\frac{\text { Developed }}{\underline{\text { Countries }}}$ & $\begin{array}{c}0.070 \\
(28.18)\end{array}$ & $\begin{array}{c}0.146 \\
(41.51)\end{array}$ & $\begin{array}{l}0.029 \\
(5.31)\end{array}$ & $\begin{array}{l}-0.025 \\
(6.25)\end{array}$ & 14,758 \\
\hline $\begin{array}{l}\text { • United } \\
\text { Kingdom }\end{array}$ & $\begin{array}{c}0.106 \\
(11.93)\end{array}$ & $\begin{array}{c}0.165 \\
(16.08)\end{array}$ & $\begin{array}{l}0.029 \\
(1.54)\end{array}$ & $\begin{array}{l}-0.079 \\
(5.12)\end{array}$ & 1,737 \\
\hline - Ireland & $\begin{array}{l}0.087 \\
(4.98)\end{array}$ & $\begin{array}{l}0.098 \\
(4.76)\end{array}$ & $\begin{array}{l}0.089 \\
(2.81)\end{array}$ & $\begin{array}{l}-0.067 \\
(1.67)\end{array}$ & 394 \\
\hline $\begin{array}{l}\text { - Western } \\
\text { Europe }\end{array}$ & $\begin{array}{c}0.091 \\
(13.40)\end{array}$ & $\begin{array}{c}0.145 \\
(18.10)\end{array}$ & $\begin{array}{l}0.072 \\
(5.78)\end{array}$ & $\begin{array}{l}-0.033 \\
(2.64)\end{array}$ & 2,606 \\
\hline $\begin{array}{l}\text { - Southern } \\
\text { Europe }\end{array}$ & $\begin{array}{l}0.042 \\
(9.31)\end{array}$ & $\begin{array}{c}0.130 \\
(15.42)\end{array}$ & $\begin{array}{l}0.015 \\
(1.04)\end{array}$ & $\begin{array}{l}-0.014 \\
(2.58)\end{array}$ & 3,328 \\
\hline - Eastern Europe & $\begin{array}{l}0.043 \\
(6.18)\end{array}$ & $\begin{array}{l}0.092 \\
(9.87)\end{array}$ & $\begin{array}{l}0.005 \\
(0.39)\end{array}$ & $\begin{array}{l}-0.022 \\
(1.49)\end{array}$ & 1,880 \\
\hline • Former USSR & $\begin{array}{c}0.075 \\
(10.21)\end{array}$ & $\begin{array}{c}0.149 \\
(14.55)\end{array}$ & $\begin{array}{l}0.045 \\
(3.92)\end{array}$ & $\begin{array}{l}-0.024 \\
(1.78)\end{array}$ & 1,649 \\
\hline - Canada & $\begin{array}{c}0.110 \\
(12.90)\end{array}$ & $\begin{array}{c}0.165 \\
(16.00)\end{array}$ & $\begin{array}{l}0.025 \\
(1.37)\end{array}$ & $\begin{array}{l}-0.074 \\
(4.33)\end{array}$ & 1,985 \\
\hline $\begin{array}{l}\text { - Australia, New } \\
\text { Zealand }\end{array}$ & $\begin{array}{l}0.108 \\
(6.38)\end{array}$ & $\begin{array}{l}0.203 \\
(8.06)\end{array}$ & $\begin{array}{l}0.053 \\
(1.54)\end{array}$ & $\begin{array}{l}-0.064 \\
(3.09)\end{array}$ & 467 \\
\hline - Japan & $\begin{array}{l}0.080 \\
(5.65)\end{array}$ & $\begin{array}{l}0.126 \\
(6.67)\end{array}$ & $\begin{array}{l}0.011 \\
(0.36)\end{array}$ & $\begin{array}{l}-0.071 \\
(2.98)\end{array}$ & 712 \\
\hline $\begin{array}{l}\text { Less-Developed } \\
\text { Countries }\end{array}$ & $\begin{array}{c}0.045 \\
(54.13)\end{array}$ & $\begin{array}{c}0.149 \\
(77.83)\end{array}$ & $\begin{array}{c}0.045 \\
(17.25)\end{array}$ & $\begin{array}{l}-0.016 \\
(15.82)\end{array}$ & 69,532 \\
\hline - Mexico & $\begin{array}{c}0.018 \\
(13.14)\end{array}$ & $\begin{array}{c}0.094 \\
(17.27)\end{array}$ & $\begin{array}{l}0.023 \\
(3.74)\end{array}$ & $\begin{array}{l}-0.012 \\
(8.43)\end{array}$ & 27,757 \\
\hline - Cuba & $\begin{array}{l}0.043 \\
(6.87)\end{array}$ & $\begin{array}{c}0.136 \\
(14.39)\end{array}$ & $\begin{array}{l}0.015 \\
(1.36)\end{array}$ & $\begin{array}{l}-0.018 \\
(1.91)\end{array}$ & 2,331 \\
\hline - Caribbean & 0.038 & 0.120 & 0.037 & -0.012 & 4,812 \\
\hline
\end{tabular}




\begin{tabular}{|c|c|c|c|c|c|}
\hline & $(9.18)$ & $(17.46)$ & (3.53) & $(2.47)$ & \\
\hline $\begin{array}{l}\text { - Central and } \\
\text { South America- } \\
\text { Spanish }\end{array}$ & $\begin{array}{c}0.036 \\
(16.74)\end{array}$ & $\begin{array}{c}0.128 \\
(21.63)\end{array}$ & $\begin{array}{l}0.036 \\
(5.97)\end{array}$ & $\begin{array}{l}-0.019 \\
(7.74)\end{array}$ & 10,023 \\
\hline $\begin{array}{l}\text { - Central and } \\
\text { South America- } \\
\text { non-Spanish }\end{array}$ & $\begin{array}{l}0.065 \\
(6.94)\end{array}$ & $\begin{array}{l}0.119 \\
(6.93)\end{array}$ & $\begin{array}{l}0.088 \\
(3.23)\end{array}$ & $\begin{array}{l}-0.033 \\
(2.79)\end{array}$ & 589 \\
\hline • Indochina & $\begin{array}{l}0.037 \\
(9.40)\end{array}$ & $\begin{array}{c}0.152 \\
(18.29)\end{array}$ & $\begin{array}{l}0.051 \\
(4.61)\end{array}$ & $\begin{array}{l}-0.012 \\
(2.67)\end{array}$ & 3,730 \\
\hline - Philippines & $\begin{array}{c}0.073 \\
(10.08)\end{array}$ & $\begin{array}{c}0.153 \\
(15.61)\end{array}$ & $\begin{array}{l}0.032 \\
(3.19)\end{array}$ & $\begin{array}{l}-0.030 \\
(2.55)\end{array}$ & 3,379 \\
\hline - China & $\begin{array}{c}0.076 \\
(14.58)\end{array}$ & $\begin{array}{c}0.145 \\
(20.79)\end{array}$ & $\begin{array}{c}0.104 \\
(10.60)\end{array}$ & $\begin{array}{l}-0.019 \\
(2.47)\end{array}$ & 3,973 \\
\hline - South Asia & $\begin{array}{c}0.098 \\
(16.48)\end{array}$ & $\begin{array}{c}0.183 \\
(24.86)\end{array}$ & $\begin{array}{l}0.041 \\
(4.90)\end{array}$ & $\begin{array}{l}-0.043 \\
(3.67)\end{array}$ & 4,624 \\
\hline $\begin{array}{l}\text { - Other South } \\
\text { Asia }\end{array}$ & $\begin{array}{l}0.067 \\
(6.03)\end{array}$ & $\begin{array}{c}0.168 \\
(11.12)\end{array}$ & $\begin{array}{l}0.020 \\
(0.94)\end{array}$ & $\begin{array}{l}-0.040 \\
(2.58)\end{array}$ & 854 \\
\hline • Korea & $\begin{array}{l}0.057 \\
(6.03)\end{array}$ & $\begin{array}{l}0.100 \\
(9.09)\end{array}$ & $\begin{array}{l}0.027 \\
(1.63)\end{array}$ & $\begin{array}{l}-0.035 \\
(2.15)\end{array}$ & 1,890 \\
\hline - Middle East & $\begin{array}{c}0.076 \\
(12.89)\end{array}$ & $\begin{array}{c}0.156 \\
(19.44)\end{array}$ & $\begin{array}{l}0.034 \\
(3.13)\end{array}$ & $\begin{array}{l}-0.036 \\
(3.29)\end{array}$ & 3,436 \\
\hline $\begin{array}{l}\text { - Sub Saharan } \\
\text { Africa }\end{array}$ & $\begin{array}{l}0.060 \\
(8.85)\end{array}$ & $\begin{array}{c}0.128 \\
(14.01)\end{array}$ & $\begin{array}{l}0.016 \\
(1.21)\end{array}$ & $\begin{array}{l}-0.038 \\
(3.70)\end{array}$ & 2,134 \\
\hline
\end{tabular}

Notes: (a) Heteroscedasticity consistent "t” statistics in parentheses.

(b) Computed using the realized matches procedure with the mode as the reference level of schooling.

The same variables as in Table 2 are held constant.

Coefficients in column (i) based on a single education variable, in columns (ii) to (iv) based on ORU technique.

Source: United States Census of Population, 2000, one percent sample, PUMS file.

According to Table 7, the return to years of actual education is 7 percent among immigrants from developed countries, and only 4.5 percent for immigrants from lessdeveloped countries. It ranges from around two percent (Mexico) to 11 percent (UK, Canada and Australia/New Zealand). In comparison, the return to the reference level of education for both the developed and less-developed categories is around 15 percent, though when the separate birthplace regions are considered it ranges from 10 to 20 percent. Most estimates of the return to the typical level of education are between 12 and 16 percent. For each birthplace group, the return to required education exceeds the return to actual education, with the difference in these estimates being between one (Ireland) and 12 (Indochina) percentage points. 
The estimated returns to surplus education are all positive, and greater for immigrants from less-developed countries than for those from developed countries. Ten of the estimates for the separate birthplace regions do not differ significantly from zero. In each instance the return to surplus education is less than the return to the typical level of education. Thus, there is little extra return to education from being in an occupation for which the person has "too much" education.

The estimated impact of undereducation is negative for each birthplace group, and all but one is statistically significant at the 10 percent level. This "earnings penalty" is more important for immigrants from developed countries than it is for those from lessdeveloped countries. Another way of looking at these results is that workers with a relatively low level of education who are working in jobs where a higher level of education than they actually possess is typical do better if they are from less-developed countries. Applying Chiswick's (1978) ability/motivation hypothesis, this suggest that immigrants with low levels of education from the advanced countries are less favorably selected for labor market success in the US (or have less relevant apprenticeships or onthe-job training) than immigrants from less advanced countries.

The results for Mexico are particularly instructive. An extra year of actual schooling increases earnings among Mexican immigrants by only 2 percent. But if this extra year of schooling is associated with an appropriate increase in occupational attainment, the effect of the increase by one year in required or typical education is 9 percent. The effect of being undereducated is -1.2 percent per year. Mexican immigrants are more likely to be undereducated and among the undereducated to have a larger average deficit than any other origin. Thus, the greater tendency to work in occupations in which native-born men have a much higher level of schooling, combined with unmeasured ability traits/self-selection that enable them to secure and retain those jobs, gives the appearance of a very small relation between formal schooling and earnings.

Table 8 presents the decomposition of the difference in the return to education for the foreign born by country of birth. Results are not presented for countries with sample sizes of less than 1,000 , as the small number of observations affects the precision of the decomposition, which is based on predictions within education categories for each birthplace. 
The countries are listed in Table 8 using the broad developed/less developed distinction of earlier tables. There are two features of the Table 8 results. First, reflecting the differences in the aggregate-level findings for developed and less-developed countries, there is a positive relationship between the payoff to actual schooling within a birthplace group and the modal years of schooling. Second, for any modal level of schooling there is considerable variation in the payoffs to schooling, and this rises with the modal level of schooling. For example, at a mode of 12 years of schooling, the payoff ranges from 3.8 percent to 4.7 percent (Central and South America, Spanish and Cuba, respectively). At 16 years as the modal level of schooling, the payoff ranges from 6.3 percent (Korea) to 11.1 percent (Canada). Obviously there are other factors at work, and the most obvious of these is the level of economic development of the countries the immigrants came from.

The columns of Table 8 can be compared to ascertain the source of the variation in the payoffs to schooling for the particular birthplace groups and the native born. Hence, the difference between columns (ii) and (i) shows the contribution of the difference in the effect of schooling due to the difference in the partial effects on earnings of overeducation, undereducation and correctly matched education between immigrants and the native born. Similarly, the difference between columns (iii) and (ii) shows the impact of the different extent of overeducation and undereducation within education levels for immigrants and the native born. Finally, the difference between columns (iv) and (iii) shows the effect that the different distribution of the level of education of immigrants and that of the native born has on the gap between the payoffs to schooling, while column (v) reports the simple difference between the payoff to schooling between the particular immigrant group and the native born (10.5 percent).

Table 8

Implied Payoffs to Schooling, Analysis Disaggregated by Country of Birth

\begin{tabular}{|l|c|c|c|c|c|c|}
\hline \multicolumn{1}{|c|}{ Country } & $\begin{array}{c}\text { (i) } \\
\text { No } \\
\text { Adjustment }\end{array}$ & (ii) & (iii) & (iv) & $\begin{array}{c}\text { (v) } \\
\mathbf{1 0 . 5}-\text { (i) }\end{array}$ & $\begin{array}{c}\text { Modal } \\
\text { Years }\end{array}$ \\
\hline $\begin{array}{l}\text { Developed } \\
\text { Countries }\end{array}$ & 7.1 & 9.7 & 9.9 & 10.5 & 3.4 & 16 \\
\hline \multicolumn{7}{|c|}{$76 \%$} \\
\hline \multicolumn{7}{|c|}{$6 \%$} \\
\hline
\end{tabular}




\begin{tabular}{|c|c|c|c|c|c|c|}
\hline - United Kingdom & 10.8 & 10.6 & 11.1 & 10.5 & $(0.3)$ & 16.0 \\
\hline \multicolumn{7}{|c|}{$(200 \%)$} \\
\hline - Western Europe & 9.3 & 10.2 & 10.8 & 10.5 & 1.2 & 14.0 \\
\hline \multicolumn{7}{|c|}{$(25 \%)$} \\
\hline - Southern Europe & 4.1 & 8.5 & 8.8 & 10.5 & 6.4 & 12.0 \\
\hline \multicolumn{7}{|c|}{$27 \%$} \\
\hline - Eastern Europe & 4.6 & 9.9 & 10.2 & 10.5 & 5.9 & 12.0 \\
\hline \multicolumn{7}{|c|}{$90 \%$} \\
\hline - Former USSR & 7.9 & 9.7 & 10.4 & 10.5 & 2.6 & 16.0 \\
\hline \multicolumn{7}{|c|}{$69 \%$} \\
\hline - Canada & 11.1 & 11.0 & 11.1 & 10.5 & $(0.6)$ & 16.0 \\
\hline \multicolumn{7}{|c|}{$(100 \%)$} \\
\hline $\begin{array}{l}\text { Less Developed } \\
\text { Countries }\end{array}$ & 4.7 & 8.3 & 8.5 & 10.5 & 5.8 & 12.0 \\
\hline \multicolumn{7}{|c|}{$62 \%$} \\
\hline - Mexico & 1.8 & 7.1 & 7.5 & 10.5 & 8.7 & 5.5 \\
\hline \multicolumn{7}{|c|}{$34 \%$} \\
\hline - Cuba & 4.7 & 8.6 & 9.3 & 10.5 & 5.8 & 12.0 \\
\hline \multicolumn{7}{|c|}{$67 \%$} \\
\hline - Caribbean & 3.8 & 8.3 & 8.6 & 10.5 & 6.7 & 12.0 \\
\hline \multicolumn{7}{|c|}{$67 \%$} \\
\hline $\begin{array}{l}\text { - Central and South } \\
\text { America - Spanish }\end{array}$ & 3.8 & 7.9 & 8.3 & 10.5 & 6.7 & 12.0 \\
\hline \multicolumn{7}{|c|}{$61 \%$} \\
\hline - Indochina & 4.3 & 8.3 & 8.3 & 10.5 & 6.2 & 14.0 \\
\hline \multicolumn{7}{|c|}{$65 \%$} \\
\hline - Philippines & 7.4 & 9.4 & 10.2 & 10.5 & 3.1 & 16.0 \\
\hline \multicolumn{7}{|c|}{$65 \%$} \\
\hline - China & 8.0 & 9.6 & 9.5 & 10.5 & 2.5 & 17.5 \\
\hline \multicolumn{7}{|c|}{$64 \%$} \\
\hline - South Asia & 10.4 & 10.3 & 10.4 & 10.5 & 0.1 & 16.0 \\
\hline \multicolumn{7}{|c|}{$(100) \%$} \\
\hline - Korea & 6.3 & 10.4 & 10.5 & 10.5 & 4.2 & 16.0 \\
\hline \multicolumn{7}{|c|}{$98 \%$} \\
\hline - Middle East & 7.7 & 9.4 & 10.1 & 10.5 & 2.8 & 16.0 \\
\hline \multicolumn{4}{|c|}{$61 \%$} & & & \\
\hline - Sub Sahara Africa & 6.3 & 9.4 & 9.9 & 10.5 & 4.2 & 16.0 \\
\hline \multicolumn{4}{|c|}{$74 \%$} & & & \\
\hline
\end{tabular}

Notes:

Numbers in the country name row indicate partial effects of schooling on earnings under our different assumptions (columns (i) to (v)). Numbers in the row below in italics indicate the contribution the difference between adjacent columns makes to the difference between the payoffs to schooling for the native born and the foreign born, where numbers in parentheses signify a higher value for the foreign born than for the native born.

(i) Implied Payoff to schooling for foreign birthplace groups, no adjustment.

(ii) Payoff to schooling for foreign birthplace group assuming same earnings effects to overeducation, undereducation and correctly matched education as the native born.

(iii) Payoff to schooling for foreign birthplace group assuming as for (ii) but also same levels of overeducation, undereducation and correctly matched education within each schooling category as the 
native born.

(iv) Payoff to schooling for foreign birthplace group assuming as for (iii) but also assuming same distribution across schooling categories for the foreign born as for the native born.

(v) Payoff to schooling for native born (10.5) minus implied payoff to schooling for foreign born birthplace groups, no adjustment.

Source: Authors' calculations.

Consider the first row of data, for immigrants from developed countries. Examination of the data for this birthplace aggregate shows that about three-quarters of the 3.4 percentage point difference in the payoff to schooling for this group of immigrants and the native born (column (v)) is due to the different earnings effects to overeducation, undereducation and correctly matched education for the two birthplace groups $[(9.7-7.1) \div 3.4=0.76]$. About one-fifth is due to the different distributions across schooling categories of immigrants from developed countries and the native born $[(10.5-9.9) \div 3.4=0.18]$. Percentage breakdowns of this type are given in italics beneath each decomposition.

Immigrants from Canada and the United Kingdom, both advanced Englishspeaking countries for whom origin skills have a very high degree of transferability to the US, have a payoff to schooling that actually exceeds that for the native born. The various adjustments considered in the table have little impact on the implied payoff to schooling for these immigrants. Because of the relatively lower direct cost of the migration process, including adjustment to the US labor market, they would be less intensely favorably selected than economic immigrants from other developed countries (Chiswick (1999)).

In the case of less-developed countries, at the aggregate level, 62 percent of the 5.8 percentage point difference in the payoff to schooling compared to the native born is attributed to different earnings effects in the ORU model, a minimal amount is linked to different distributions of the workforces across the overeducated, undereducated and correctly matched categories conditional upon each level of schooling, and 34 percent is due to different distributions across schooling categories.

These results show that the decomposition technique outlined above, and applied to the total foreign-born sample in Table 2, is robust to the choice of sample. The main finding is that between 60 and 75 percent of the difference in the payoffs to schooling between immigrants from specific birthplace groups and the native born is due to the 
earnings consequences of the education categories specified in the ORU earnings model. An exception is the large partial effect of schooling for immigrants from the Englishspeaking developed countries, who presumably have a very high degree of skill transferability to the US labor market.

\section{THE ROLE OF AGE AT MIGRATION}

Chiswick (1978) raised the possibility that the smaller partial effect of schooling for the foreign born was due to schooling acquired abroad. He investigated this issue by partitioning the schooling variable into its pre-immigration and post-immigration components. This required the use of information on self-reported year of arrival in the US, which was available only in broad categories in the 1970 US Census data employed in the analysis. It was also based on the assumption that schooling is a continuous activity from the time it starts until it ends. Chiswick (1978, p.911) reported that "an extra year of schooling prior to immigration raises earnings by 5.8 percent, while an extra year after immigration raises earnings by 5.0 percent.” In other words, the pattern of effects is contrary to that expected, perhaps because of the broad year of immigration intervals.

More recently, Friedberg (2000) conducted analyses for Israel, where she had actual year of immigration, and showed that the payoff to the schooling immigrants acquired abroad was significantly less than that to schooling they obtained in Israel. For the native born, the payoff to schooling was 10.0 percent, while for immigrants the payoffs were 7.1 percent for schooling obtained abroad and 8.0 percent for schooling obtained in Israel (Friedberg, 2000, Table 5).

The specific year of immigration is also recorded in the 2000 US Census data. It is still necessary, however, to assume that schooling is a continuous activity. Possible consequences of this assumption are addressed through a sensitivity analysis.

In the current application of the ORU model to the analysis of immigrants' earnings the preferred approach is to partition the sample into those immigrants who completed their schooling prior to arrival in the US (termed adult immigrants for brevity), and those immigrants who obtained at least some of their schooling in the US (termed 
child immigrants for brevity). ${ }^{20}$ This allows for a straightforward application of the ORU model without the need to partition schooling into its "acquired abroad" and "acquired domestically" components. Separate analyses using the ORU specification of the earnings function are then conducted for adult and child immigrants.

The hypotheses advanced earlier should apply in full to adult immigrants. Hence, it would be expected that, due to positive selection, they would have relatively good earnings outcomes if undereducated, and, due to the less-than-perfect international transferability of the human capital they acquire in their country of origin, relatively poor earnings outcomes if overeducated. There are different expectations for child immigrants who are largely tied movers rather than primary decision makers, and who have obtained at least the final years (and sometimes all) of their schooling in the US. ${ }^{21}$ Such immigrants should be less favorably selected for migration than adult immigrants, and the earnings consequences associated with positive selection among adult immigrants (better earnings outcomes among the undereducated) should not be pronounced among them. Moreover, because child immigrants complete their schooling in the US, the international transferability of human capital should be less of an issue for them, either because all their schooling was acquired in the US, or because the component of their schooling acquired in the US increases the transferability of schooling obtained in the country of origin. $^{22}$ Hence, the wage effects of overeducation should be more aligned with those of the native born than with those of adult immigrants.

\footnotetext{
${ }^{20}$ Assuming uninterrupted schooling, adult immigrants are those for whom the age at immigration exceeds their number of years of schooling plus six years. Those for whom the age at immigration was less than the number of years of schooling plus six are considered child immigrants in this analysis.

${ }^{21}$ It is recognized that this may not, in reality, reflect the location of immigrants' schooling, but it follows from the assumptions made in this section.

${ }^{22}$ Assuming that schooling is not interrupted, estimation of an earnings function for the child immigrant sample with the schooling variable (mean of 14 years) disaggregated into schooling acquired in the US (mean of 6.8 years) and schooling acquired abroad (mean of 7.2 years) indicated that (i) the payoff to schooling acquired in the US was about one percentage point more than the payoff to schooling acquired abroad (payoffs of 11.6 and 10.4 percent, respectively); and (ii) schooling acquired in the US increased the return to
} 
Because it relies on the assumption that schooling is a continuous activity, from the time it starts to the time it ends, and also on the Census data on year of arrival being accurate, the categorization of adult immigrants as those who arrived in the US after the completion of their schooling (age of arrival greater than the years of schooling plus 6) may result in too many or too few immigrants being viewed as having completed their schooling abroad (with obvious carry-over to the child immigrant sample). Hence, the computations are repeated for alternative definitions of year of immigration.

Selected results from this analysis are presented in Tables 9 and 10. These are for the education variable from the conventional earnings model and for the three education variables in the ORU specification of the earnings model for both child immigrants and adult immigrants under the various assumptions for ascertaining this status discussed above. Table 9 is for child immigrants, and Table 10 for adult immigrants. The findings for the native born from Table 2 are also presented in bold for reference purposes in both tables.

schooling acquired abroad, although while this impact was statistically significant it was economically of minor importance. 
Table 9

Coefficients on Education Variables in Conventional and ORU Models for Child Immigrants, Various Definitions of Child Immigrants

\begin{tabular}{|c|c|c|c|c|c|}
\hline $\begin{array}{l}\text { Definition of } \\
\text { Child Immigrant } \\
\text { based on }\end{array}$ & $\begin{array}{c}\text { (i) } \\
\text { Actual } \\
\text { Education }\end{array}$ & $\begin{array}{c}\text { (ii) } \\
\text { Reference } \\
\text { Education }\end{array}$ & $\begin{array}{c}\text { (iii) } \\
\text { Over- } \\
\text { Education }\end{array}$ & $\begin{array}{c}\text { (iv) } \\
\text { Under- } \\
\text { Education }\end{array}$ & $\begin{array}{c}(v) \\
\text { Sample Size }\end{array}$ \\
\hline $\begin{array}{l}\text { Census Year of } \\
\text { Arrival }+4\end{array}$ & $\begin{array}{c}0.114 \\
(42.50)\end{array}$ & $\begin{array}{c}0.163 \\
(50.09)\end{array}$ & $\begin{array}{c}0.057 \\
(10.75)\end{array}$ & $\begin{array}{l}-0.086 \\
(16.05)\end{array}$ & 15,705 \\
\hline $\begin{array}{l}\text { Census Year of } \\
\text { Arrival }+3\end{array}$ & $\begin{array}{c}0.113 \\
(44.98)\end{array}$ & $\begin{array}{c}0.163 \\
(53.39)\end{array}$ & $\begin{array}{c}0.058 \\
(11.65)\end{array}$ & $\begin{array}{l}-0.084 \\
(16.40)\end{array}$ & 17,545 \\
\hline $\begin{array}{l}\text { Census Year of } \\
\text { Arrival }+2\end{array}$ & $\begin{array}{c}0.110 \\
(46.86)\end{array}$ & $\begin{array}{c}0.161 \\
(55.74)\end{array}$ & $\begin{array}{c}0.057 \\
(12.37)\end{array}$ & $\begin{array}{l}-0.079 \\
(16.91)\end{array}$ & 19,847 \\
\hline $\begin{array}{l}\text { Census Year of } \\
\text { Arrival }+1\end{array}$ & $\begin{array}{c}0.108 \\
(50.29)\end{array}$ & $\begin{array}{c}0.160 \\
(59.64)\end{array}$ & $\begin{array}{c}0.056 \\
(13.07)\end{array}$ & $\begin{array}{l}-0.076 \\
(17.71)\end{array}$ & 22,490 \\
\hline $\begin{array}{l}\text { Census Year of } \\
\text { Arrival }\end{array}$ & $\begin{array}{c}0.105 \\
(52.46)\end{array}$ & $\begin{array}{c}0.156 \\
(61.29)\end{array}$ & $\begin{array}{c}0.055 \\
(13.89)\end{array}$ & $\begin{array}{l}-0.073 \\
(18.20)\end{array}$ & 25,359 \\
\hline $\begin{array}{l}\text { Census Year of } \\
\text { Arrival }-1\end{array}$ & $\begin{array}{c}0.101 \\
(53.89)\end{array}$ & $\begin{array}{c}0.152 \\
(62.68)\end{array}$ & $\begin{array}{c}0.053 \\
(13.97)\end{array}$ & $\begin{array}{l}-0.070 \\
(19.19)\end{array}$ & 28,567 \\
\hline $\begin{array}{l}\text { Census Year of } \\
\text { Arrival }-2\end{array}$ & $\begin{array}{c}0.099 \\
(56.99)\end{array}$ & $\begin{array}{c}0.152 \\
(66.27)\end{array}$ & $\begin{array}{c}0.052 \\
(14.58)\end{array}$ & $\begin{array}{l}-0.068 \\
(20.70)\end{array}$ & 32,073 \\
\hline $\begin{array}{l}\text { Census Year of } \\
\text { Arrival }-3\end{array}$ & $\begin{array}{c}0.096 \\
(59.15)\end{array}$ & $\begin{array}{c}0.152 \\
(67.99)\end{array}$ & $\begin{array}{c}0.051 \\
(14.99)\end{array}$ & $\begin{array}{l}-0.063 \\
(21.50)\end{array}$ & 35,568 \\
\hline $\begin{array}{l}\text { Census Year of } \\
\text { Arrival }-4\end{array}$ & $\begin{array}{c}0.093 \\
(61.89)\end{array}$ & $\begin{array}{c}0.151 \\
(71.02)\end{array}$ & $\begin{array}{c}0.050 \\
(15.65)\end{array}$ & $\begin{array}{l}-0.058 \\
(22.53)\end{array}$ & 39,055 \\
\hline $\begin{array}{l}\text { Native Born } \\
\text { from Table } 2\end{array}$ & $\begin{array}{c}0.106 \\
(202.11)\end{array}$ & $\begin{array}{c}0.154 \\
(254.62)\end{array}$ & $\begin{array}{c}0.056 \\
(52.26)\end{array}$ & $\begin{array}{c}-0.067 \\
(69.42)\end{array}$ & 533,906 \\
\hline
\end{tabular}

Note: Coefficient in column (i) based on a single education variable, in columns (ii) to (iv) based on the ORU technique.

Source: United States Census of Population, 2000, one percent sample, PUMS file.

The middle row of Table 9 (in bold) presents findings based on the use of the census information on year of arrival. It shows a payoff to school for immigrants who completed their schooling in the US of 10.5 percent, which is essentially the same as the 10.6 percent payoff for the native born (see the bottom row of Table 9). The payoff to years of education that are typical in the immigrants' occupations is 15.6 percent, which again is essentially the same as the payoff received by the native born. Similarly, the payoff to years of overeducation for child immigrants is 5.5 percent, which matches the 5.6 percent payoff for the native born. Years of undereducation are associated with an "earnings penalty" of 7.3 percent among child immigrants, and 6.7 percent among the 
native born. These outcomes are consistent with the hypotheses advanced above, that there is minimal selection effects among child immigrants, and, given the nature of their education, the less-than-perfect international transferability of human capital skills should have less impact on their labor market success.

While the year of arrival in the US would be a significant event for immigrants, and hence is likely to be recalled reasonably accurately, some rounding to threshold years (ending in five, and especially in zero) is apparent in the data, that is, there is bunching in the frequency distribution of immigrants at these years. This suggests that measurement error should be taken seriously. As the way of defining child immigrants changes, there are modest changes in the estimated coefficients (Table 9). A tightening of the criteria (moving up the table from the bold center line to the top, and reducing the sample of child immigrants) is associated with small increases in the payoff to actual years of education and to years of the reference level of education, slightly larger increases in the earnings penalty associated with years of undereducation, but no material change in the earnings effects of years of overeducation. Relaxing the criteria (moving down the table from the bold center line, and increasing the sample of child immigrants) is, predictably, associated with opposite changes in the estimates. While the changes are small when comparisons are made between adjacent rows, they amount to differences of several percentage points when the extremes of Table 9 are considered. These results indicate, however, that child immigrants who complete their schooling in the US appear to have payoffs to schooling that are very similar to the native born.

The results for adult immigrants presented in Table 10 mirror reasonably well the results for all immigrants. This follows from their numerical importance in the overall sample. The small changes in the criteria for categorizing immigrants to adult immigrant status between adjacent rows in Table 10 do not impact unduly on the findings, though there are differences of up to one percentage point when the extremes of the samples used in this table are examined. Adult immigrants are characterized by selection in immigration, which impacts on the effect that undereducation has on earnings, and by less-than-perfect international transferability of the human capital they obtained abroad, which impacts on the earnings effects of years of overeducation. 
Table 10

Coefficients on Education Variables in Conventional and ORU Models for Adult Immigrants, Various Definitions of Adult Immigrants

\begin{tabular}{|c|c|c|c|c|c|}
\hline $\begin{array}{l}\text { Definition of } \\
\text { Adult Immigrant } \\
\text { based on }\end{array}$ & $\begin{array}{c}\text { (i) } \\
\text { Actual } \\
\text { Education }\end{array}$ & $\begin{array}{c}\text { (ii) } \\
\text { Reference } \\
\text { Education }\end{array}$ & $\begin{array}{c}\text { (iii) } \\
\text { Over- } \\
\text { Education }\end{array}$ & $\begin{array}{c}\text { (iv) } \\
\text { Over- } \\
\text { Education }\end{array}$ & $\begin{array}{c}\text { (v) } \\
\text { Sample Size }\end{array}$ \\
\hline $\begin{array}{l}\text { Census Year of } \\
\text { Arrival }+4\end{array}$ & $\begin{array}{c}0.047 \\
(57.34)\end{array}$ & $\begin{array}{c}0.152 \\
(77.81)\end{array}$ & $\begin{array}{c}0.039 \\
(14.60)\end{array}$ & $\begin{array}{l}-0.019 \\
(18.81)\end{array}$ & 68,585 \\
\hline $\begin{array}{l}\text { Census Year of } \\
\text { Arrival }+3\end{array}$ & $\begin{array}{c}0.046 \\
(56.16)\end{array}$ & $\begin{array}{c}0.152 \\
(75.93)\end{array}$ & $\begin{array}{c}0.038 \\
(13.91)\end{array}$ & $\begin{array}{l}-0.019 \\
(18.65)\end{array}$ & 66,745 \\
\hline $\begin{array}{l}\text { Census Year of } \\
\text { Arrival }+2\end{array}$ & $\begin{array}{c}0.046 \\
(54.94)\end{array}$ & $\begin{array}{c}0.153 \\
(74.08)\end{array}$ & $\begin{array}{c}0.037 \\
(13.27)\end{array}$ & $\begin{array}{c}-0.019 \\
(18.38)\end{array}$ & 64,443 \\
\hline $\begin{array}{l}\text { Census Year of } \\
\text { Arrival }+1\end{array}$ & $\begin{array}{c}0.045 \\
(53.12)\end{array}$ & $\begin{array}{c}0.152 \\
(71.42)\end{array}$ & $\begin{array}{c}0.036 \\
(12.52)\end{array}$ & $\begin{array}{l}-0.019 \\
(18.02)\end{array}$ & 61,800 \\
\hline $\begin{array}{l}\text { Census Year of } \\
\text { Arrival } \\
\text { Census Year of } \\
\text { Arrival - } 1\end{array}$ & $\begin{array}{c}\mathbf{0 . 0 4 4} \\
(\mathbf{5 1 . 3 4 )} \\
0.043 \\
(49.56)\end{array}$ & $\begin{array}{c}\mathbf{0 . 1 5 4} \\
(\mathbf{6 9 . 7 2 )} \\
0.157 \\
(67.94)\end{array}$ & $\begin{array}{c}\mathbf{0 . 0 3 4} \\
\mathbf{( 1 1 . 6 1 )} \\
0.034 \\
(11.12)\end{array}$ & $\begin{array}{c}\mathbf{- 0 . 0 1 8} \\
(\mathbf{1 7 . 4 4 )} \\
-0.018 \\
(16.55)\end{array}$ & 58,931 \\
\hline $\begin{array}{l}\text { Census Year of } \\
\text { Arrival }-2\end{array}$ & $\begin{array}{c}0.041 \\
(47.09)\end{array}$ & $\begin{array}{c}0.158 \\
(64.70)\end{array}$ & $\begin{array}{c}0.032 \\
(10.15)\end{array}$ & $\begin{array}{c}-0.017 \\
(15.75)\end{array}$ & 52,217 \\
\hline $\begin{array}{l}\text { Census Year of } \\
\text { Arrival }-3\end{array}$ & $\begin{array}{c}0.040 \\
(44.53)\end{array}$ & $\begin{array}{c}0.159 \\
(62.35)\end{array}$ & $\begin{array}{c}0.032 \\
(10.15)\end{array}$ & $\begin{array}{l}-0.016 \\
(14.84)\end{array}$ & 48,722 \\
\hline $\begin{array}{l}\text { Census Year of } \\
\text { Arrival }-4\end{array}$ & $\begin{array}{c}0.038 \\
(41.71)\end{array}$ & $\begin{array}{c}0.160 \\
(58.95)\end{array}$ & $\begin{array}{l}0.030 \\
(8.68)\end{array}$ & $\begin{array}{c}-0.015 \\
(13.86)\end{array}$ & 45,235 \\
\hline $\begin{array}{l}\text { Native Born } \\
\text { from Table } 2\end{array}$ & $\begin{array}{c}0.106 \\
(202.11)\end{array}$ & $\begin{array}{c}0.154 \\
(254.62)\end{array}$ & $\begin{array}{c}0.056 \\
(52.26)\end{array}$ & $\begin{array}{c}-0.067 \\
(69.42)\end{array}$ & 533,906 \\
\hline $\begin{array}{l}\text { All Foreign } \\
\text { Born from } \\
\text { Table } 2 \\
\end{array}$ & $\begin{array}{c}0.052 \\
(66.51)\end{array}$ & $\begin{array}{c}0.153 \\
(91.66)\end{array}$ & $\begin{array}{c}0.044 \\
(18.41)\end{array}$ & $\begin{array}{c}-0.021 \\
(21.30)\end{array}$ & 84,290 \\
\hline
\end{tabular}

Note: Coefficient in column (i) based on a single education variable, in columns (ii) to (iv) based on the ORU technique.

Source: United States Census of Population, 2000, one percent sample, PUMS file.

The findings for adult immigrants in the middle row of Table 10 were used in the decomposition whose methodology is outlined in Table 6. Results are available from the authors upon request. The results of this decomposition mirror findings for all immigrants presented in Table 6. The factors associated with a lower earnings penalty to years of undereducation, suggested above to be linked to positive selection in immigration, account for slightly more than 60 percent of the lower payoff to schooling among adult immigrants. 


\section{CONCLUSION}

The finding that the payoff to schooling for adult men in the US is substantially less for the foreign born than that for the native born, documented by Chiswick (1978) for the 1970 Census, and by many other authors for later censuses and for other countries, is also a very strong feature of the data from the 2000 US Census. The analyses above show that while the native born have a payoff to an extra year of schooling of 10.6 percent, the payoff for the foreign born is only one-half of this, 5.2 percent.

However, when the focus is on correctly matched education, defined as working in an occupation where one's level of education is typical, the foreign born and native born have similar earnings increments, of around 15.4 percent higher earnings per year of correctly matched education. The decomposition establishes that it is undereducation rather than overeducation that is the main contributor to the lower payoff to schooling for the foreign born.

Undereducation appears to be linked to positive selection in immigration, whereas overeducation is linked to the less-than-perfect international transferability of immigrants' human capital skills. The most striking feature of the analyses that distinguish between years of overeducation, undereducation and correctly matched education, however, is the strong relative performance of immigrants with less education than is typical for the occupations in which they work. This suggests an unmeasured ability variable and positive selectivity in migration.

The framework outlined in this paper shows that this strong performance is responsible, in large part (around two-thirds) for the seemingly lower payoff to schooling for the foreign born. An exception is immigrants from the English-speaking developed countries that are so similar to the US that there is a high degree of transferability of skills and a low cost of migration (implying a weaker positive self-selectivity), and hence a payoff to schooling comparable to that of the US native born.

Tests of robustness are conducted through separate analyses by level of economic development, by country of origin, and by age at migration (child vs adult at migration). Child immigrants show earnings patterns similar to the native born which are quite different from those of immigrants who arrived after completing their schooling. 
While this framework can account for the differences in payoffs to schooling for the foreign born and native born, it does not explain the difference. Important concerns are the reasons behind the higher earnings of foreign-born "undereducated" men relative to native-born undereducated men, and the high proportion of immigrant men working in occupations in which their education level is substantially below that of the average (mean or modal) level. The most obvious candidate is the superior ability/motivation of the foreign born associated with self-selection in migration, as outlined in Chiswick (1978, 1999). The method applied above appears to provide a means of quantifying the importance of this self-selection that has to date proved to be a rather elusive concept.

The analysis also suggests that the two related issues of selectivity in migration and the international transferability of skills are both relevant, but their relative importance will vary by country of origin and educational attainment. For immigrants with very low skill levels, transferability is not much of an issue, and selectivity becomes dominant. For high-skilled immigrants with a high degree of skill transferability (such as Canadian and UK immigrants to the US, those who immigrated to the US as children, and presumably also internal migration of natives in the US) the schooling-earnings patterns in the ORU analysis for the migrants will look similar to that of the natives/nonmovers.

While answering several questions, this paper does highlight additional questions and issues. One is to analyze even further the determinants of the disparity between the typical education level in the respondent's occupation and the respondent's own educational attainment. Another is to delve more into the occupational mobility of immigrants, and in particular analyze the ORU model as a function of duration in the destination. A third is to determine the extent to which the different effects of schooling on earnings by motive for migrating and visa class - economic, kinship and refugee - can be explained within the context of the ORU model. While this methodological study has focused the empirical application on men, it would be worthwhile to expand the model to explicitly incorporate labor supply decisions and apply the technique to women. Finally, while this paper incorporates several tests for robustness, the application of the methodology to other destinations and other time periods would provide additional tests of robustness. 


\section{REFERENCES}

Baker, Michael, and Benjamin, Dwayne (1994). “The Performance of Immigrants in the Canadian Labor Market”, Journal of Labor Economics, Vol. 12, No. 3, pp. 369405.

Beggs, John J. and Chapman, Bruce J., (1988). "Immigrant Wage Adjustment in Australia” Cross-Section and Time-Series Estimation”, Economic Record, Vol. 64, No. 186, pp.161-167.

Chiswick, Barry R., (1978). "The Effect of Americanization on the Earnings of Foreign-born Men”, Journal of Political Economy, Vol. 86, No. 5, pp. 897-921.

Chiswick, Barry R., (1979). "The Economic Progress of Immigrants: Some Apparently Universal Patterns”, pp. 357-99 in William Fellner (ed) Contemporary Economic Problems 1979, American Enterprise Institute for Public Policy Research, Washington, D.C..

Chiswick, Barry R., (1999). “Are Immigrants Favorably Self-Selected?” American Economic Review, Vol. 89, No. 2, pp. 181-185.

Chiswick, Barry R., (2003). "Jacob Mincer, Experience and the Distribution of Earnings”. Review of Economics of the Household, Vol. 1, No. 4, pp.343-361/

Chiswick, Barry R., Lee, Yew Liang and Miller, Paul W., (2005). “A Longitudinal Analysis of Immigrant Occupational Mobility: A Test of the Immigrant Assimilation Hypothesis”, International Migration Review, Vol. 39, No. 2, pp.332-353.

Chiswick, Barry R. and Miller Paul W., (2007). "The International Transferability of Immigrants’ Human Capital Skills”, IZA-Institute for the Study of Labor Discussion Paper No. 2670, Bonn, Germany.

Cohn, Elchanan. and Khan, Shahina., (1995). "The Wage Effects of Overschooling Revisited”, Labor Economics, Vol. 2, No. 1, pp. 67-76.

Daly, Mary. C., Buchel, Felix, and Duncan, Greg. J., (2000). "Premiums and Penalties for Surplus and Deficit Education: Evidence from the United States and Germany”, Economics of Education Review, Vol. 19, No. 2, pp. 169-178.

Duncan, Greg. and Hoffman, Saul. D., (1981). “The Incidence and Wage Effects of Overeducation”, Economics of Education Review, Vol. 1, No. 1, pp. 75-86.

Dustmann, Christian, (1993). "Earnings Adjustment of Temporary Migrants", Journal of Population Economics, Vol. 6, No. 2, pp.153-168. 
Friedberg, Rachel M., (2000). "You Can’t Take it with You? Immigrant Assimilation and the Portability of Human Capital”, Journal of Labor Economics, Vol. 18, No. 2, pp.221-251.

Groot, Wim, (1996). "The Incidence of, and Returns to Overeducation in the UK", Applied Economics, Vol. 28, No. 10, pp.1345-1350.

Hartog, Joop., (2000). "Over-education and Earnings: Where Are We, Where Should We Go?”, Economics of Education Review, Vol. 19, No. 2, pp. 131-147.

Jaeger, David A., (1997). "Reconciling the Old and New Census Bureau Education Questions: Recommendations for Researchers", Journal of Business and Economic Statistics, Vol. 15, No. 3, pp. 300-309.

Jasso, Guillermina, Rosenzweig, Mark R., and Smith, James P., (2002). "The Earnings of US Immigrants: World Skill Prices, Skill Transferability and Selectivity”, mimeo, New York University.

Kiker, Billy. F., Santos, M Maria. C. and Mendes De Oliveira, M., (1997). "Overeducation and Undereducation: Evidence for Portugal”, Economics of Education Review, Vol. 16, No. 2, pp. 111-125.

McGuinness, Seamus, (2006). "Overeducation in the Labour Market”, Journal of Economic Surveys, Vol. 20, No. 3, pp.387-418.

Rumberger, Russell, W. (1981). "The Rising Incidence of Overeducation in the U.S. Labor Market”, Economics of Education Review, Vol. 1 , No. 3, pp. 293-314.

Shields, Michael A. and Wheatley Price, Stephen, (1998). "The Earnings of Male Immigrants in England: Evidence from the Quarterly LFS”, Applied Economics, Vol. 30, pp.1157-1168.

Verdugo, Richard. and Verdugo, Naomi. (1989). “The Impact of Surplus Schooling on Earnings: Some Additional Findings”, Economics of Education Review, Vol. 22, No. 4, pp. 690-695. 
January 2008

Statistical Appendices to:

"Why is the Payoff to Schooling Smaller for Immigrants?"

\author{
Barry R. Chiswick \\ University of Illinois at Chicago \\ and \\ IZA Institute for the Study of Labor \\ and \\ Paul W. Miller \\ University of Western Australia
}

\title{
APPENDIX A
}

\section{COMPILING THE REQUIRED EDUCATION DATA}

Education: This is formed from the question "What is the highest degree or level of school that this person has completed". The categorical data in the Census were converted to a continuous variable using the following scheme.

\begin{tabular}{|c|c|}
\hline Education Category & Assumed level of Education \\
\hline No schooling completed & 0 \\
\hline Nursery school to $4^{\text {th }}$ grade & 2 \\
\hline $5^{\text {th }}$ grade or $6^{\text {th }}$ grade & 5.5 \\
\hline $7^{\text {th }}$ grade or $8^{\text {th }}$ grade & 7.5 \\
\hline $9^{\text {th }}$ grade & 9 \\
\hline $10^{\text {th }}$ grade & 10 \\
\hline $11^{\text {th }}$ grade & 11 \\
\hline $12^{\text {th }}$ grade, no diploma & 11.5 \\
\hline High School graduate & 12 \\
\hline $\begin{array}{l}\text { Some college credit, but less than } 1 \\
\text { year }\end{array}$ & 12.5 \\
\hline 1 or more years of college, no degree & 14 \\
\hline Associate degree & 14 \\
\hline Bachelor’s degree & 16 \\
\hline Master's degree & 17.5 \\
\hline Professional degree & 18.5 \\
\hline Doctorate degree & 20 \\
\hline
\end{tabular}

The modal level of education for some birthplace groups is quite low. For example, for immigrants from Mexico it is 5.5 years. This is to be interpreted as the 
modal education category being " $5^{\text {th }}$ grade or $6^{\text {th }}$ grade", and not as indicating the presence of two modes.

Variations in coding schemes may result in different estimates of the payoff to schooling, though Jaeger's (1997) work shows that these are likely to be small in relation to the differences that are the focus of the current study. Moreover, Jaeger (1997) shows that the differences in the results are associated with features of the various imputation algorithms at the upper end of the educational distribution, and as there are more modest differences between the foreign born and the native born here than at the lower end of the educational distribution, it is unlikely that the particular imputation method used in this study is crucial.

Occupation: All individuals who had worked between 1995 and 2000 were asked to provide information on their occupation. Information provided by all these respondents is used in preference to that on subsets (e.g. only persons who worked in 1999). This will generate more precise estimates. However, particularly when the mode is used, but also for the mean-based analyses, the use of alternative samples to construct the reference levels of education for each occupation has little impact on the results.

Information on the modal level of schooling for male workers aged 25-64 years is provided in Table A.1

Table A.1

Distribution of Workers by Required Level of Schooling

\begin{tabular}{|l|c|}
\hline Modal Level of Schooling & \% of Adult Male Workers \\
\hline 12 & 60.33 \\
14 & 11.26 \\
16 & 23.90 \\
17.5 & 2.30 \\
18.5 & 1.96 \\
20 & 0.24 \\
\hline Total & 100.00 \\
\hline
\end{tabular}




\section{APPENDIX B}

Mean Schooling and Incidence of Over- and Under-Education by Country of Birth, Males 25-64, 2000 U.S. Census

\begin{tabular}{|c|c|c|c|c|}
\hline & $\begin{array}{c}\text { Mean Schooling } \\
\text { (years) }\end{array}$ & $\begin{array}{l}\% \text { correctly } \\
\text { matched }\end{array}$ & $\begin{array}{c}\% \\
\text { overeducated }\end{array}$ & $\%$ undereducated \\
\hline Native Born & 13.665 & 80.23 & 12.17 & 7.60 \\
\hline Foreign Born & 11.874 & 61.87 & 14.07 & 24.05 \\
\hline \multicolumn{5}{|l|}{ Region of Birth } \\
\hline Developed Countries & 14.091 & 69.84 & 19.62 & 10.54 \\
\hline - United Kingdom & 15.020 & 72.38 & 20.35 & 7.28 \\
\hline - Ireland & 14.064 & 74.11 & 15.68 & 10.21 \\
\hline • Western Europe & 14.967 & 68.26 & 24.57 & 7.17 \\
\hline - Southern Europe & 12.013 & 67.53 & 10.76 & 21.71 \\
\hline - Eastern Europe & 13.882 & 71.80 & 20.67 & 7.54 \\
\hline - Former USSR & 15.003 & 61.93 & 32.69 & 5.38 \\
\hline - Canada & 14.728 & 75.24 & 16.74 & 8.02 \\
\hline - Australia \& NZ & 13.739 & 73.89 & 14.85 & 11.27 \\
\hline - Japan & 15.211 & 74.22 & 19.90 & 5.88 \\
\hline Less-Developed Countries & 11.397 & 60.16 & 12.88 & 26.96 \\
\hline - Mexico & 8.411 & 49.90 & 3.62 & 46.49 \\
\hline - Cuba & 12.611 & 69.89 & 12.37 & 17.74 \\
\hline - Caribbean & 12.029 & 74.03 & 8.20 & 17.77 \\
\hline $\begin{array}{l}\text { - Central and South } \\
\text { America-Spanish }\end{array}$ & 11.096 & 62.26 & 10.10 & 27.64 \\
\hline $\begin{array}{l}\text { - Central and South } \\
\text { America-non Spanish }\end{array}$ & 12.620 & 76.99 & 7.97 & 15.04 \\
\hline • Indo China & 12.018 & 74.57 & 8.16 & 17.27 \\
\hline • Philippines & 14.356 & 71.79 & 23.97 & 4.25 \\
\hline - China & 14.747 & 60.77 & 27.64 & 11.58 \\
\hline - South Asia & 15.740 & 61.59 & 33.47 & 4.94 \\
\hline - Other South Asia & 14.505 & 61.74 & 28.68 & 9.58 \\
\hline • Korea & 14.896 & 69.92 & 25.14 & 4.94 \\
\hline - Middle East & 14.703 & 64.05 & 27.20 & 8.75 \\
\hline - Sub Sahara Africa & 14.608 & 64.96 & 27.91 & 7.13 \\
\hline
\end{tabular}

Source: United States Census of Population, 2000, one percent sample, PUMS file.

The data for Appendix B have been computed by compiling the educational requirements of the jobs using the mean educational attainment of all workers in each of the 510 three-digit occupations. Workers whose level of schooling is more (less) than one standard deviation higher than the mean are categorized as "overeducated" ("undereducated"). Those within one standard deviation of the mean educational attainment of their occupation are categorized as "correctly matched". 
Given that the standard deviation of education within occupations exceeds one, the incidence of correctly matched workers is greater under the mode then under the mean plus/minus one standard deviation. In the regression analyses based on the mean, however, the exact difference between the respondents' education and the mean in his occupation determine the number of years of under/over education. 


\section{APPENDIX C}

Regression Estimates of Earnings Equations, Total Adult Men in Paid Employment, Over/Under Education based on Modal Education, U.S. 2000

\begin{tabular}{|c|c|c|c|c|c|c|}
\hline \multirow[b]{2}{*}{ Variable } & \multicolumn{3}{|c|}{ Native Born } & \multicolumn{3}{|c|}{ Foreign Born } \\
\hline & (i) & (ii) & Mean/(SD) & (iv) & (v) & Mean/(SD) \\
\hline Constant & $\begin{array}{c}4.347 \\
(192.98)\end{array}$ & $\begin{array}{c}3.763 \\
(167.06)\end{array}$ & $\begin{array}{c}1.0 \\
(0.0)\end{array}$ & $\begin{array}{c}5.885 \\
(108.59)\end{array}$ & $\begin{array}{c}4.426 \\
(77.55)\end{array}$ & $\begin{array}{c}1.0 \\
(0.0)\end{array}$ \\
\hline Actual Education & $\begin{array}{c}0.106 \\
(202.11)\end{array}$ & (c) & $\begin{array}{c}13.665 \\
(2.51)\end{array}$ & $\begin{array}{c}0.052 \\
(66.51)\end{array}$ & (c) & $\begin{array}{l}11.874 \\
(4.78)\end{array}$ \\
\hline $\begin{array}{l}\text { Reference } \\
\text { Education }^{(b)}\end{array}$ & (c) & $\begin{array}{c}0.154 \\
(254.62)\end{array}$ & $\begin{array}{c}13.574 \\
(1.98)\end{array}$ & (c) & $\begin{array}{c}0.153 \\
(91.66)\end{array}$ & $\begin{array}{l}13.247 \\
(1.94)\end{array}$ \\
\hline Overeducation & (c) & $\begin{array}{c}0.056 \\
(52.26)\end{array}$ & $\begin{array}{l}0.698 \\
(1.21)\end{array}$ & (c) & $\begin{array}{c}0.044 \\
(18.41)\end{array}$ & $\begin{array}{l}0.711 \\
(1.35)\end{array}$ \\
\hline Undereducation & (c) & $\begin{array}{c}-0.067 \\
(69.42)\end{array}$ & $\begin{array}{l}0.607 \\
(1.39)\end{array}$ & (c) & $\begin{array}{c}-0.021 \\
(21.30)\end{array}$ & $\begin{array}{l}2.084 \\
(3.39)\end{array}$ \\
\hline Experience (Exp) & $\begin{array}{c}0.033 \\
(71.94)\end{array}$ & $\begin{array}{c}0.036 \\
(78.85)\end{array}$ & $\begin{array}{l}22.395 \\
(10.44)\end{array}$ & $\begin{array}{c}0.011 \\
(10.61)\end{array}$ & $\begin{array}{c}0.018 \\
(17.47)\end{array}$ & $\begin{array}{l}22.213 \\
(10.91)\end{array}$ \\
\hline $\operatorname{Exp}^{2} / 100$ & $\begin{array}{l}-0.057 \\
(55.56)\end{array}$ & $\begin{array}{c}-0.063 \\
(63.46)\end{array}$ & $\begin{array}{l}6.105 \\
(5.09)\end{array}$ & $\begin{array}{l}-0.016 \\
(7.89)\end{array}$ & $\begin{array}{l}-0.031 \\
(16.06)\end{array}$ & $\begin{array}{l}6.124 \\
(5.59)\end{array}$ \\
\hline $\begin{array}{l}\text { Logs Weeks } \\
\text { Worked }\end{array}$ & $\begin{array}{c}1.009 \\
(183.28)\end{array}$ & $\begin{array}{c}0.999 \\
(182.80)\end{array}$ & $\begin{array}{l}3.821 \\
(0.41)\end{array}$ & $\begin{array}{c}0.874 \\
(72.93)\end{array}$ & $\begin{array}{c}0.864 \\
(72.82)\end{array}$ & $\begin{array}{l}3.766 \\
(0.47)\end{array}$ \\
\hline Married & $\begin{array}{c}0.269 \\
(111.24)\end{array}$ & $\begin{array}{c}0.253 \\
(106.17)\end{array}$ & $\begin{array}{l}0.654 \\
(0.48)\end{array}$ & $\begin{array}{c}0.210 \\
(35.30)\end{array}$ & $\begin{array}{c}0.190 \\
(32.84)\end{array}$ & $\begin{array}{l}0.645 \\
(0.48)\end{array}$ \\
\hline Race (black) & $\begin{array}{c}-0.153 \\
(42.95)\end{array}$ & $\begin{array}{c}-0.135 \\
(38.19)\end{array}$ & $\begin{array}{l}0.103 \\
(0.30)\end{array}$ & $\begin{array}{c}-0.186 \\
(17.36)\end{array}$ & $\begin{array}{l}-0.127 \\
(12.18)\end{array}$ & $\begin{array}{l}0.076 \\
(0.26)\end{array}$ \\
\hline Veteran & $\begin{array}{c}-0.046 \\
(16.95)\end{array}$ & $\begin{array}{c}-0.031 \\
(11.65)\end{array}$ & $\begin{array}{l}0.240 \\
(0.43)\end{array}$ & $\begin{array}{l}-0.093 \\
(7.20)\end{array}$ & $\begin{array}{l}-0.058 \\
(4.58)\end{array}$ & $\begin{array}{l}0.050 \\
(0.22)\end{array}$ \\
\hline Metropolitan & $\begin{array}{c}0.211 \\
(35.62)\end{array}$ & $\begin{array}{c}0.189 \\
(32.29)\end{array}$ & $\begin{array}{l}0.960 \\
(0.20)\end{array}$ & $\begin{array}{l}0.132 \\
(4.92)\end{array}$ & $\begin{array}{l}0.122 \\
(4.68)\end{array}$ & $\begin{array}{l}0.990 \\
(0.10)\end{array}$ \\
\hline South & $\begin{array}{c}-0.057 \\
(24.68)\end{array}$ & $\begin{array}{c}-0.063 \\
(27.70)\end{array}$ & $\begin{array}{l}0.361 \\
(0.48)\end{array}$ & $\begin{array}{c}-0.070 \\
(11.61)\end{array}$ & $\begin{array}{c}-0.076 \\
(12.91)\end{array}$ & $\begin{array}{l}0.281 \\
(0.45)\end{array}$ \\
\hline $\begin{array}{l}\text { Speaks English Very } \\
\text { Well }\end{array}$ & $\begin{array}{c}-0.059 \\
(11.61)\end{array}$ & $\begin{array}{c}-0.064 \\
(12.79)\end{array}$ & $\begin{array}{l}0.049 \\
(0.22)\end{array}$ & $\begin{array}{l}-0.085 \\
(9.04)\end{array}$ & $\begin{array}{l}-0.070 \\
(7.72)\end{array}$ & $\begin{array}{l}0.333 \\
(0.47)\end{array}$ \\
\hline Speaks English Well & $\begin{array}{l}-0.096 \\
(7.49)\end{array}$ & $\begin{array}{l}-0.108 \\
(8.57)\end{array}$ & $\begin{array}{l}0.008 \\
(0.09)\end{array}$ & $\begin{array}{c}-0.264 \\
(26.52)\end{array}$ & $\begin{array}{l}-0.174 \\
(17.94)\end{array}$ & $\begin{array}{l}0.249 \\
(0.43)\end{array}$ \\
\hline $\begin{array}{l}\text { Speaks English Not } \\
\text { Well }\end{array}$ & $\begin{array}{l}0.006 \\
(0.33)\end{array}$ & $\begin{array}{l}-0.016 \\
(0.84)\end{array}$ & $\begin{array}{l}0.004 \\
(0.06)\end{array}$ & $\begin{array}{c}-0.369 \\
(33.52)\end{array}$ & $\begin{array}{l}-0.271 \\
(25.17)\end{array}$ & $\begin{array}{l}0.193 \\
(0.39)\end{array}$ \\
\hline $\begin{array}{l}\text { Speaks English Not } \\
\text { at All }\end{array}$ & $\begin{array}{l}0.136 \\
(1.39)\end{array}$ & $\begin{array}{l}0.022 \\
(0.24)\end{array}$ & $\begin{array}{c}0.0002 \\
(0.01)\end{array}$ & $\begin{array}{l}-0.372 \\
(26.94)\end{array}$ & $\begin{array}{l}-0.313 \\
(23.50)\end{array}$ & $\begin{array}{l}0.072 \\
(0.26)\end{array}$ \\
\hline $\begin{array}{l}\text { Years since } \\
\text { Migration (YSM) }\end{array}$ & (c) & (c) & (c) & $\begin{array}{l}0.009 \\
(9.58)\end{array}$ & $\begin{array}{c}0.010 \\
(11.92)\end{array}$ & $\begin{array}{l}16.621 \\
(10.95)\end{array}$ \\
\hline
\end{tabular}




\begin{tabular}{|lcccccc|}
\hline $\mathrm{YSM}^{2} / 100$ & (c) & (c) & (c) & -0.008 & -0.011 & 3.961 \\
& & & & $(3.91)$ & $(5.60)$ & $(4.78)$ \\
Citizen & (c) & (c) & (c) & 0.073 & 0.072 & 0.414 \\
& & & & $(10.94)$ & $(11.10)$ & $(0.49)$ \\
$\overline{\mathrm{R}}^{2}$ & 0.3348 & 0.3565 & & 0.3642 & 0.4040 & \\
Sample Size & 533,906 & 533,906 & 533,906 & 84,290 & 84,290 & 84,290 \\
\hline
\end{tabular}

Notes: (a) Heteroscedasticity consistent "t" statistics in parentheses.

(b) Computed using the realized matches procedure with the mode as the reference level of schooling.

(c) Variable not entered into specification.

Dependent variable: Natural logarithm of earnings in 1999.

Source: United States Census of Population, 2000, one percent sample, PUMS file. 


\section{APPENDIX D}

Regression Estimates of Earnings Equations, Total Adult Men in Paid Employment, Over/Under education Based on Mean Education, U.S. 2000

\begin{tabular}{|c|c|c|c|c|c|c|}
\hline \multirow[b]{2}{*}{ Variable } & \multicolumn{3}{|c|}{ Native Born } & \multicolumn{3}{|c|}{ Foreign Born } \\
\hline & (i) & (ii) & Mean/(SD) & (iv) & (v) & Mean/(SD) \\
\hline Constant & $\begin{array}{c}4.347 \\
(192.98)\end{array}$ & $\begin{array}{c}3.640 \\
(162.01)\end{array}$ & $\begin{array}{c}1.0 \\
(0.0)\end{array}$ & $\begin{array}{c}5.885 \\
(108.59)\end{array}$ & $\begin{array}{c}4.493 \\
(80.53)\end{array}$ & $\begin{array}{c}1.0 \\
(0.0)\end{array}$ \\
\hline Actual Education & $\begin{array}{c}0.106 \\
(202.11)\end{array}$ & (c) & $\begin{array}{l}13.665 \\
(2.51)\end{array}$ & $\begin{array}{c}0.052 \\
(66.51)\end{array}$ & (c) & $\begin{array}{l}11.874 \\
(4.78)\end{array}$ \\
\hline Required Education $^{(b)}$ & (c) & $\begin{array}{c}0.167 \\
(261.16)\end{array}$ & $\begin{array}{l}13.337 \\
(1.82)\end{array}$ & (c) & $\begin{array}{c}0.157 \\
(97.41)\end{array}$ & $\begin{array}{l}12.836 \\
(2.03)\end{array}$ \\
\hline Overeducation & (c) & $\begin{array}{c}0.051 \\
(45.00)\end{array}$ & $\begin{array}{l}0.874 \\
(1.16)\end{array}$ & (c) & $\begin{array}{c}0.041 \\
(16.95)\end{array}$ & $\begin{array}{l}0.883 \\
(1.36)\end{array}$ \\
\hline Undereducation & (c) & $\begin{array}{c}-0.052 \\
(44.73)\end{array}$ & $\begin{array}{l}0.543 \\
(1.19)\end{array}$ & (c) & $\begin{array}{c}-0.013 \\
(11.81)\end{array}$ & $\begin{array}{l}1.842 \\
(3.11)\end{array}$ \\
\hline Experience (Exp) & $\begin{array}{c}0.033 \\
(71.94)\end{array}$ & $\begin{array}{c}0.037 \\
(80.99)\end{array}$ & $\begin{array}{l}22.395 \\
(10.44)\end{array}$ & $\begin{array}{c}0.011 \\
(10.61)\end{array}$ & $\begin{array}{c}0.018 \\
(17.99)\end{array}$ & $\begin{array}{l}22.213 \\
(10.91)\end{array}$ \\
\hline $\operatorname{Exp}^{2} / 100$ & $\begin{array}{l}-0.057 \\
(55.56)\end{array}$ & $\begin{array}{l}-0.065 \\
(66.03)\end{array}$ & $\begin{array}{l}6.105 \\
(5.09)\end{array}$ & $\begin{array}{l}-0.016 \\
(7.89)\end{array}$ & $\begin{array}{l}-0.033 \\
(17.02)\end{array}$ & $\begin{array}{l}6.124 \\
(5.59)\end{array}$ \\
\hline $\begin{array}{l}\text { Logs Weeks } \\
\text { Worked }\end{array}$ & $\begin{array}{c}1.009 \\
(183.28)\end{array}$ & $\begin{array}{c}0.991 \\
(182.01)\end{array}$ & $\begin{array}{l}3.821 \\
(0.41)\end{array}$ & $\begin{array}{c}0.874 \\
(72.93)\end{array}$ & $\begin{array}{c}0.857 \\
(72.42)\end{array}$ & $\begin{array}{l}3.766 \\
(0.47)\end{array}$ \\
\hline Married & $\begin{array}{c}0.269 \\
(111.24)\end{array}$ & $\begin{array}{c}0.247 \\
(103.99)\end{array}$ & $\begin{array}{l}0.654 \\
(0.48)\end{array}$ & $\begin{array}{c}0.210 \\
(35.30)\end{array}$ & $\begin{array}{c}0.183 \\
(31.77)\end{array}$ & $\begin{array}{l}0.645 \\
(0.48)\end{array}$ \\
\hline Race (black) & $\begin{array}{c}-0.153 \\
(42.95)\end{array}$ & $\begin{array}{c}-0.124 \\
(35.44)\end{array}$ & $\begin{array}{l}0.103 \\
(0.30)\end{array}$ & $\begin{array}{c}-0.186 \\
(17.36)\end{array}$ & $\begin{array}{l}-0.140 \\
(13.47)\end{array}$ & $\begin{array}{l}0.076 \\
(0.26)\end{array}$ \\
\hline Veteran & $\begin{array}{c}-0.046 \\
(16.95)\end{array}$ & $\begin{array}{c}-0.033 \\
(12.39)\end{array}$ & $\begin{array}{l}0.240 \\
(0.43)\end{array}$ & $\begin{array}{l}-0.093 \\
(7.20)\end{array}$ & $\begin{array}{l}-0.065 \\
(5.15)\end{array}$ & $\begin{array}{l}0.050 \\
(0.22)\end{array}$ \\
\hline Metropolitan & $\begin{array}{c}0.211 \\
(35.62)\end{array}$ & $\begin{array}{c}0.183 \\
(31.40)\end{array}$ & $\begin{array}{l}0.960 \\
(0.20)\end{array}$ & $\begin{array}{l}0.132 \\
(4.92)\end{array}$ & $\begin{array}{l}0.074 \\
(2.83)\end{array}$ & $\begin{array}{l}0.990 \\
(0.10)\end{array}$ \\
\hline South & $\begin{array}{c}-0.057 \\
(24.68)\end{array}$ & $\begin{array}{c}-0.064 \\
(28.64)\end{array}$ & $\begin{array}{l}0.361 \\
(0.48)\end{array}$ & $\begin{array}{c}-0.070 \\
(11.61)\end{array}$ & $\begin{array}{l}-0.078 \\
(13.44)\end{array}$ & $\begin{array}{l}0.281 \\
(0.45)\end{array}$ \\
\hline $\begin{array}{l}\text { Speaks English Very } \\
\text { Well }\end{array}$ & $\begin{array}{l}-0.059 \\
(11.61)\end{array}$ & $\begin{array}{l}-0.065 \\
(13.13)\end{array}$ & $\begin{array}{l}0.049 \\
(0.22)\end{array}$ & $\begin{array}{l}-0.085 \\
(9.04)\end{array}$ & $\begin{array}{l}-0.077 \\
(8.54)\end{array}$ & $\begin{array}{l}0.333 \\
(0.47)\end{array}$ \\
\hline Speaks English Well & $\begin{array}{l}-0.096 \\
(7.49)\end{array}$ & $\begin{array}{l}-0.106 \\
(8.46)\end{array}$ & $\begin{array}{l}0.008 \\
(0.09)\end{array}$ & $\begin{array}{c}-0.264 \\
(26.52)\end{array}$ & $\begin{array}{l}-0.176 \\
(18.17)\end{array}$ & $\begin{array}{l}0.249 \\
(0.43)\end{array}$ \\
\hline $\begin{array}{l}\text { Speaks English Not } \\
\text { Well }\end{array}$ & $\begin{array}{l}0.006 \\
(0.33)\end{array}$ & $\begin{array}{l}-0.017 \\
(0.90)\end{array}$ & $\begin{array}{l}0.004 \\
(0.06)\end{array}$ & $\begin{array}{c}-0.369 \\
(33.52)\end{array}$ & $\begin{array}{l}-0.246 \\
(22.85)\end{array}$ & $\begin{array}{l}0.193 \\
(0.39)\end{array}$ \\
\hline $\begin{array}{l}\text { Speaks English Not } \\
\text { at All }\end{array}$ & $\begin{array}{l}0.136 \\
(1.39)\end{array}$ & $\begin{array}{l}0.009 \\
(0.11)\end{array}$ & $\begin{array}{l}0.0002 \\
(0.01)\end{array}$ & $\begin{array}{l}-0.372 \\
(26.94)\end{array}$ & $\begin{array}{l}-0.262 \\
(19.61)\end{array}$ & $\begin{array}{l}0.072 \\
(0.26)\end{array}$ \\
\hline $\begin{array}{l}\text { Years Since Migration } \\
\text { (YSM) }\end{array}$ & (c) & (c) & (c) & $\begin{array}{l}0.009 \\
(9.58)\end{array}$ & $\begin{array}{c}0.010 \\
(11.51)\end{array}$ & $\begin{array}{l}16.621 \\
(10.95)\end{array}$ \\
\hline $\mathrm{YSM}^{2} / 100$ & (c) & (c) & (c) & $\begin{array}{l}-0.008 \\
(3.91)\end{array}$ & $\begin{array}{l}-0.010 \\
(5.10)\end{array}$ & $\begin{array}{l}3.961 \\
(4.78)\end{array}$ \\
\hline
\end{tabular}




\begin{tabular}{|lcccccc|}
\hline Citizen & (c) & (c) & (c) & 0.073 & 0.059 & 0.414 \\
& & & & $(10.94)$ & $(9.14)$ & $(0.49)$ \\
$\overline{\mathrm{R}}^{2}$ & 0.3348 & 0.3608 & & 0.3642 & 0.4079 & \\
Sample Size & & & & & & \\
\hline
\end{tabular}

Notes: (a) = Heteroscedasticity consistent "t" statistics in parentheses.

(b) = Computed using the realized matches procedure with the mean as the reference level of schooling.

(c) = Variable not relevant or not entered into specification.

Dependent variable: Natural logarithm of earnings in 1999.

Source: United States Census of Population, 2000, one percent sample, PUMS file.

When the mean level of education of the worker's occupation is used in Appendix D to construct the required level of education, the threshold of one standard deviation is not imposed, but rather the exact difference between the mean in the occupation and the respondent's schooling is used. For example, if the respondent has 12 years of education and the mean in his occupation is 12.5, then his years of undereducation will be set of 0.5 . 